\title{
V Abulafia's Kabbalah versus other Kabbalists
}

\section{Prophecy and Individuality}

The emphasis on the reading of the parable that views it as dealing with Abulafia's own role as the son of God and the possessor of the pearl is part of the more individualistic propensity of his general approach. Under the pressure of the noetic visions he adopted from the Greek sources as mediated by Muslim and Jewish texts, Abulafia regards the paramount processes as a matter of an individual's mind and as reversible events that an aspirant may re-experience if he so chooses. He also allegorised collective events such as the Exodus from Egypt and the Sinaitic revelation. As Abulafia explicitly states: Sinai, Paradise, and the Land of Israel are analogous to a lower entity, just as the Seat of Glory, Jerusalem, and the supernal academy all represent the same entity on high, although they are reinterpreted as being related to the experience of a living person. ${ }^{1}$ I propose to designate this type of allegory as spiritualistic exegesis, ${ }^{2}$ which also reverberates in his followers' writings. ${ }^{3}$

According to Abulafia's understanding, his Kabbalah had two mains goals: one is union with God and the other is the attainment of prophecy. The former is understood as the goal of the Torah, ${ }^{4}$ and the various expressions of Abulafia's unitive vision have been analysed in detail elsewhere. ${ }^{5}$ The second one, which I have analysed in a separate study, is discussed in numerous instances in Abulafia's texts. ${ }^{6}$ However, I would like to adduce one more expression of the centrality of this ideal. In the introduction to his Mafteah ha-Hokhmot, Abulafia writes:

From the entire Torah, the prophet will indeed only pursue that which is sufficient to bring him to prophecy. Since what does it matter whether the world is eternal or created? This will not add any degree to him or diminish his degree because of this; it will not add to his rank and will not diminish his rank. ${ }^{7}$

This seems to me to be a fundamental statement on Abulafia's attitude towards the special nature of the topics that are found in the Bible: neither the theological nor the cosmological ones are conceived as important, but only a human's psychological

1 See Sitrei Torah, 90.

2 See Idel, Language, Torah, and Hermeneutics, xvi-xvii. This has to do with a strong individualist tendency in Maimonides's Guide. See also Ralph Lerner, "Maimonides' Governance of the Solitary," in Perspectives on Maimonides, 33-46.

3 For example, see the anonymous treatise from his school, Sefer ha-Seruf, 1: היכנס חי לגן עדן.

4 Introduction to his Mafteah ha-Hokhmot, 32.

5 Idel, Studies in Ecstatic Kabbalah, 1-31.

6 Idel, "Definitions of Prophecy: Maimonides and Abulafia.” See also Mafteah ha-Šemot, 163.

7 Mafteah ha-Hokhmot, 38:

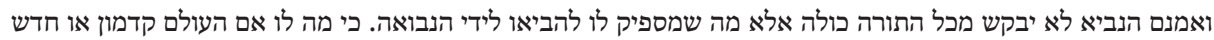

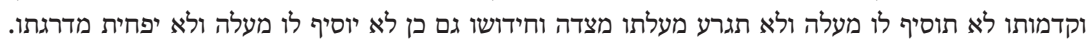


transformation into a prophet. In this context, we should take into consideration a statement from the same book-which will be quoted in Appendix B-to the effect that he wrote his commentary on the Pentateuch only for those who prophesy.

As seen above, the true operation is the inner change. To be sure: a serious scholar does not have to accept the self-presentation of the author that he is studying, but in Abulafia's case, the content of his writings abundantly sustains those statements as to what is or is not central for him. In any case, Abulafia envisions the purpose of the Torah in a manner that explicitly contradicts the Rabbinic statement that prophecy had already ceased, ${ }^{8}$ a view adopted by many thinkers, though not all Jewish ones, in the Middle Ages. ${ }^{9}$ Unlike for the Rabbinic authorities, for Abulafia, the ultimate aim of the Torah is to bring people to prophecy.

Let me provide one more example of his allegorical understanding of a vital topic in biblical and Rabbinic Judaism: the ancient Temple ritual. In one of his epistles, Abulafia writes:

Whoever wants to come into the Temple and to enter its inmost part should sanctify himself by the sanctity of the high priest, and should study and teach and keep and do $^{10}$ until he becomes perfect in his ethical and intellectual attributes, and then he should seclude himself ${ }^{11}$ in order to receive the prophetic influx from the mouth of the Dynamis. ${ }^{12}$

8 Ephraim E. Urbach, “When Did Prophecy Cease?” in Me-'Olamam Šel Ḥakhamim, ed. Ephraim E. Urbach (Jerusalem: Magnes Press, 1988): 9-20; Ephraim E. Urbach, "Prophet and Sage in the Jewish Heritage," in Collected Writings in Jewish Studies, eds. Robert Brody and Moshe D. Herr (Jerusalem: Hebrew University Magnes Press, 1999): 393-403; Philip S. Alexander, “A Sixtieth Part of Prophecy: The Problem of Continuing Revelation in Judaism," in Words Remembered, Texts Renewed: Essays in Honour of John F. A. Sawyer, eds. Jon Davies, Graham Harvey, and Wilfred G.E. Watson (Sheffield: Sheffield Academic Press, 1995): 414-33; Alon Goshen-Gottstein, “'The Sage is Superior to the Prophet': The Conception of Torah through the Prism of the History of Jewish Exegesis" [Hebrew], in Study and Knowledge in Jewish Thought, 2:37-77; Joseph Dan, "The End of Prophecy and Its Significance to Jewish Thought" [Hebrew], Alppayyim 30 (2007): 257-88; Stephen L. Cook, On the Question of the "Cessation of Prophecy" in Ancient Judaism (Tübingen: Mohr Siebeck, 2011); and especially Benjamin D. Sommer, "Did Prophecy Cease? Evaluating a Reevaluation,” Journal of Biblical Literature 115 (1996): 31-47.

9 As to the medieval material, see the rich material collected and analysed in Amos Goldreich, $\mathrm{Au}$ tomatic Writing in Zoharic Literature and Modernism [Hebrew] (Los Angeles: Cherub Press, 2010), 912; Huss, "A Sage Is Preferable Than a Prophet," 103-39; Wolfson, "Sage Is Preferable to Prophet." 10 Cf. Avot 4:5.

11 Yitboded. This term can also be translated here as "concentrate." See Idel, Studies in Ecstatic Kabbalah, 103-69.

12 Mașref la-Kesef, Ms. Sassoon 56, fols. 33b-34a, ed. Gross (Jerusalem: 2001), 23:

צריך הרוצה לבוא אל בית המקדש ולהיכנס לפני לפנים, להתקדש בקדושת כהן גדול וללמוד וללמד לשמור ולעשות עד שישלם במדותיו ובדבריותיו, ואז יתבודד כדי לקבל השפע הנבואי לפי לפי מפי הגבורה.

Let me point out that I proposed to distinguish between ecstatic Kabbalah, which is less interested in place but rather seeks to emphasise the importance of the human being's perfection, versus theosophical-theurgical Kabbalah, which is much more concerned with place and with the emendation of the divine sphere. See my "The Land of Israel in Jewish Mystical Thought" [Hebrew], in The Land of Israel in Medieval Jewish Thought, 207-8, 211. In my opinion, this claim is true both emicly 
Abulafia himself was not of priestly extraction, nor was he especially interested in rebuilding a material Temple ${ }^{13}$ or even in the Jews' return to the Land of Israel, despite his belief that he was the Messiah. We know for sure that he was an Israelite, ${ }^{14}$ and as such, he could not, Halakhically speaking, serve as a priest-Kohen-still less a high priest. Thus, according to his own criterion, if we take his words on the level of their plain sense, he could not become a prophet.

Interestingly enough, he claims that he received a tradition that the Messiah would build the supernal Jerusalem by means of the divine name before the terrestrial Temple would be built, a passage that I understand to be dealing with the human intellect. ${ }^{15}$ Though emicly speaking, Abulafia believes he is dealing with the real temple and does not actually subvert what he saw as the authentic understanding of this concept, from a Rabbinic or etic point of view, he subverts the traditional understanding of the Temple as such, as well as the importance of the special space in general.

In two discussions, one in the context of the parable of the pearl and again in a parallel to this context, Abulafia claims that the best of the Israelites are the Levites, that the best of the Levites are the priests, and that the priests are considered to be prophets. ${ }^{16}$ The ecstatic Kabbalist's assumption that the high priest's experience in

(in what the Kabbalists themselves claim) and eticly (what can be observed by an outsider). However, Haviva Pedaya, in "The Divinity as Place and Time and the Holy Place in Jewish Mysticism," in Sacred Space: Shrine, City, Land, eds. Benjamin Z. Kedar and Raphael J. Zwi Werblowsky (London: Palgrave Macmillan, 1998): 95, claims that theosophical Kabbalah is also concerned with the form of man and his activity and thus in this way is similar to ecstatic Kabbalah. In this case, it contradicts the emic, theomorphic, and theocentric approaches of the theosophical Kabbalists, which I consider to be correct, although it is true that it empowers the human being. Pedaya simply confuses the emic and the etic categories. See also below chapter 25 note 84. Given Abulafia's reduction of the ideal humanity to the intellect and the divine to a sublime, separate intellect, the idea of theomorphism as merely dealing with both the human and the divine limbs is a gross religious misunderstanding.

13 The only possible exception is a brief reference to the building of the temple in Sefer ha-Ot, 69, though immediately afterwards, he mentions the letters of the names of 72 and 42 letters that were revealed to him as something to be performed now; another exception may be his Oșar 'Eden Ganuz, 2:8, 272. I assume that the passage about the Temple is part of the national/historical narrative.

14 See Mafteah ha-Šemot, 148.

15 Mafteaḥ ha- ̌̌emot, 100-101:

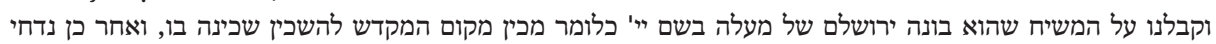

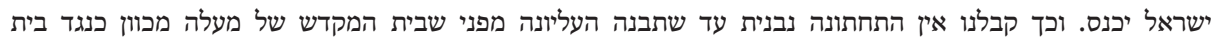

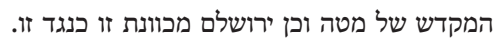

I have not found the source of such a tradition.

16 See the Hebrew text of Or ha-Śekhel below in Appendix A, paragraph [d], where an English translation is also provided. See also Oșar 'Eden Ganuz, 1:10, 190, 3:8, 337. This claim does not fit Abulafia's own extraction at all as he was an Israelite. See his confession in Mafteah ha-Šemot, 149. The tripartite distinction between the three degrees of the Jews is found in many instances in Abulafia's writings. See also his Šomer Mișwah, 14-15. Interestingly enough, in Sitrei Torah, 73, he equates the words 
the Temple was a prophetic one has very little, if anything at all, to do with the manner in which the ancient ritual is perceived in Rabbinic sources, transformative and apotheotic as the experience of the high priest was conceived to be, as has been pointed out by Michael Schneider. ${ }^{17}$

In fact, Abulafia understands the high priest as comprising all the other Jews, as well as the Gentiles, as part of his vision of the highest individual being more universal than the lowest ones, who are sublated by the process of elevation. In a manner reminiscent of the way in which Abulafia describes God as both the simplest and the most complex entity, the "distinguished man" and high priest sublate the lower forms that comprise humanity into a higher one.

The particularist figure of the high priest in Rabbinic Judaism, who is mainly conceived as performing a very specific and concrete ritual once a year for the welfare of the people of Israel, is-in Abulafia's philosophical allegorisation-transposed into the most spiritual and universal figure. A mystic who sometimes uses the specific gesture of the blessing priest alone in a secluded room when there is no one to be blessed, not on a special day of the year but rather on any day or night, and not in a special place in the space that the community deems important, is, in my opinion, an anomian practitioner. ${ }^{18}$

Understood in terms of Rabbinic Judaism, where there is no linkage between the concept of priesthood and the phenomenon of prophecy, this prophetic understanding of the high priest is quite an absurd claim. At least in the biblical material, there are often conflicts between the two forms of Jewish religious leadership; the manner in which Abulafia presents the hierarchy we are discussing here is absurd according to its plain sense and requires an allegorical interpretation, which can be found in his writings. The Kabbalist, however, describes the mystical experience as being related to a feeling of being anointed, which may have something to do with the anointing of the high priest, the king, and-important for the manner in which Abulafia understood himself-the Messiah. ${ }^{19}$ In fact, in the figure of the Messiah, Abulafia unifies the three ancient elites: the king, the high priest, and the prophet, all of them conceived as irrelevant in the exilic situation.

Kohen Gadol ("high priest") with ha-Nevi'im ("the prophets") = 118. For the gematria of 118, see Appendix A below.

17 See his The Appearance of the High Priest-Theophany, Apotheosis and Binitarian Theology: From Priestly Tradition of the Second Temple Period through Ancient Jewish Mysticism [Hebrew] (Los Angeles: Cherub Press, 2012).

18 See Idel, The Mystical Experience, 29-30. See especially Sefer ha-Hešeq, 16, where Abulafia's technique is described in terms that are identical to the priestly blessing. However, it should be pointed out that this blessing was not part of what happened in the Holy of Holies, where the service was silent, unlike Abulafia's recitation of the combinations of the letters. See Israel Knohl, The Sanctuary of Silence: The Priestly Torah and the Holiness School (Minneapolis: Fortress, 1995), and Israel Knohl, "Between Voice and Silence: The Relationship between Prayer and Temple Cult," JBL 115, no. 1 (1996): 17-30, and its pertinent bibliography.

19 Idel, The Mystical Experience, 76-77. 
Abulafia's interpretation of themes related to the Temple is allegorical and is reminiscent of the views of Philo and Plotinus on this topic, ${ }^{20}$ though I have no reason to assume any direct influence from their writings. In this case, the impact of Maimonides's Neo-Aristotelianism was the main reason for the allegorical interpretations that permeate Abulafia's approach. As with the philosophers mentioned above, Abulafia is concerned with private experience, unlike the ancient Jewish "Templar" ritual in which the high priest is the representative of all the Israelites, who are understood to be both a corporate collective and private individuals. To judge from a passage found in the epistle we are dealing with here that parallels passage [d] from Or ha-Śekhel, the priest stands for the intellectual faculty. ${ }^{21}$ This is also the case in a discussion found in Abulafia's Untitled Treatise. ${ }^{22}$

In a way, Abulafia opens the possibility of a more democratic understanding of this ritual: "whoever wants to come." However, his concepts of perfection and seclusion represent a much more elitist approach, and are part of an epistle that was most probably written to one of his disciples. In any case, I am not acquainted with any discussions in Kabbalistic texts concerning the dramatic allegorisation and democratisation of the ancient ritual-indeed, the high priest was only ever one person at a time. In my opinion, this interpretation belongs to what I call the third narrative, to be distinguished from the much more widespread allegorical understandings of the Temple as a microcosm that reflects the structure of the macrocosmos found in a variety of ancient and medieval sources, including Rabbi Baruch Togarmi and Abulafia himself. ${ }^{23}$ This latter understanding may belong to what I called the second narrative, as it is concerned with the rituals of the nation.

20 See Moshe Idel, "Hitbodedut: On Solitude in Jewish Mysticism," in Einsamkeit, eds. Aleida and Jan Assmann (Munich: Fink, 2000): 192-98; Idel, Messianic Mystics, 96-97, 361, note 148; Scholem, Major Trends in Jewish Mysticism, 123, 378, note 9; and, more generally, the comprehensive study by Ron Margolin, The Human Temple: Religious Interiorization and the Structuring of Inner Life in Early Hasidism [Hebrew] (Jerusalem: Magnes Press, 2005). See, more recently, Avraham Elqayam, "Nudity in the Sanctus Sanctorum: Philo and Plotinus on Nudity, Esthetics and Sanctity" [Hebrew], Kabbalah 28 (2012): 301-21. As to Pedaya's claim that Abulafia's view of the Temple was influenced by Sufi views, there is no proof. She attributed the threefold division of the Temple as corresponding to three parts of the human body as well as to the macrocosmos, which had actually already been discussed by Rabbi Judah ha-Levi (Kuzari), Rabbi Ezra of Gerona, and Rabbi Baruch Togarmi, to Abulafia without referring to any of his writings. See my "Sefer Yetzirah and Its Commentaries," 482, note 59. See also chapter 27 note 186 below.

21 See Mașref la-Kesef, 7-9. See also Sefer Toledot Adam, Ms. Oxford, Bodleian 836, fol.154a, where the high priest refers to the intellect in habitus. Interestingly enough, Sefer Ner Elohim, a treatise from Abulafia's school that deals with the priestly blessing and mentions the high priest many times, does not use philosophical allegoresis in order to interpret the role of the high priest. This is just one of the reasons why I think that this book was not written by Abulafia himself.

22 Ms. Firenze, Laurenziana, Plut., II, 48, fol. 98b, where the actualisation of the human intellect, the Selem, is described as a lower temple. For the allegorisation of the Tabernacle in the Pseudo-Maimonidean Iggeret ha-Mussar, see my Language, Torah, and Hermeneutics, 45-46.

23 See, for the time being, Idel, "Definitions of Prophecy: Maimonides and Abulafia," 33, note 21. 
It is difficult to avoid the conclusion that the person whom Abulafia described to be entering the Temple was Abulafia himself, although intended solely in an allegorical manner. In his Oșar 'Eden Ganuz, he describes the end of a period of negative experiences as God "brought me into the palace of holiness." 24 The single exception to such an interiorisation of the concept of the Temple seems to be a much later text that was written in the fifteenth century. In this text, the anonymous Sefer Toledot Adam, the impact of Abulafia's writings is quite obvious. There, it is said that after becoming a philosopher, astrologer, and a person capable of conjuring angels, demons, and liliths, and of reaching the rank of prophecy and beings illuminated by the light of God, the aspirant then arrives at an even higher rank, an event that is described as follows:

And cleave to Him and your soul unites with the Creator of the Berešit and will cleave to All and will be able to perform wonders on earth and will enter into the chambers of chambers together with the King, the Lord of Seva'ot, and you will be called the Palace of the Lord, ${ }^{25}$ the Palace of the Lord, two times [...] this is the reason why you will be able to be one of those who see the face of the King and be illuminated by the light of life. Remember and do not forget. ${ }^{26}$

The description of entering of the chambers where God is found is quite reminiscent of the high priest in the ancient Temple. In the above cases, the spiritual sense is, most evidently, not accompanied by an actual performance of the Temple ritual, as the Jewish Temple had been destroyed many centuries previously. In fact, Abulafia's Kabbalah's concentration on the techniques for pronouncing the divine names represents a qualified continuation, and even more, a replacement, perhaps even a displacement, of the most important ritual performed in the ancient Temple: the high priest's pronunciation of the divine name as the culmination of the ritual of the Day of Atonement.

However, although in both cases, the divine name is the focus of the ritual, the details of its pronunciation differ dramatically, and I am confident that Abulafia was well-aware of this divergence, since he invented the details and the general structure

24 3:10, 370: יביאני אל היכל הקדש והוא הזמן שבו השלמתי הספר הזה אשר חברתיו פה במסיני. In his Mafteah ha-Šemot, 26, Abulafia claims that Kabbalists identify the holy palace with the intellectual soul and the holy spirit with the intellect. Thus, we have clear indications as to the existence of a more sustained inner, or third, narrative. For his secluded room as a sanctuary where a person meets the divine, see Idel, The Mystical Experience, 34. Let me point out that Abulafia compares the Israelites to the "people of the plain sense" (אנשי הפשט) and to the body, certainly not a compliment, but rather an attitude that reflects his ambivalence towards the chosenness of the Jewish nation as understood in traditional texts. See his Šomer Mișwah, 14-15.

25 In Ms. Firenze, Laurenziana, Plut. II. 48, fol. 71a, the Agent Intellect is allegorised as the "Palace of God."

26 Ms. Oxford, Bodleian 836, fol. 156a:

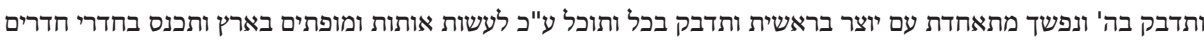

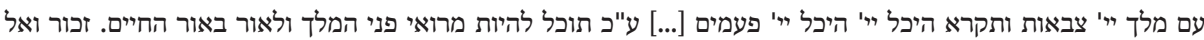


of those techniques. Or, to put it a different way: Abulafia does not continue or enhance the ancient ritual, but rather its dramatic abrogation. The person now conceived as a high priest is not a priest; the chamber of seclusion is not a temple; the time is not a special moment in the year, but whenever one would like to perform the technique; the divine name is not what is pronounced in those techniques. What is dramatically different is the fact that no one is blessed because the technique is performed in total isolation. While a few elements are used, its ritualistic logicthe culmination of the Temple ritual, taking place in a special space, performed by the representative of the Jewish people acting in a privileged moment of the year-has been abrogated.

Abulafia's extreme spiritualisation opens the question as to whether the assumption that the actual performance of Jewish rituals as formulated in Rabbinic literature is indeed necessary for understanding the manner in which his Kabbalah functioned. Let me nuance the question: given the detailed descriptions of the techniques Abulafia offered, it is strange that he does not specify a preliminary requirement of keeping the commandments in order to enter the path of prophetic Kabbalah, or of integrating the performance of the commandments as an essential part of the technique he described.

In our specific case, the question may be asked whether the spiritual interpretation of the parable is necessarily dependent on the assumption of the veracity of the historical narrative, and in my opinion, the answer is no. According to what I call Abulafia's third narrative, the high priest, like the Messiah (both of whom played an important role in the Jewish popular imagination), is now considered to be a paradigmatic, ideal figure for modelling a spiritualised inner life, independent of his historical role or even his existence. ${ }^{27}$ This ambivalent attitude towards fundamental aspects of biblical and Rabbinic forms of Judaism is paramount for understanding Abulafia: though not necessarily denying the validity of the second narrative, he conceives it to be marginal at best to an individual's spiritual life in the present and the ideal life in general.

In our case, it seems evident that Abulafia's techniques function as an alternative to (and are conceived as being higher than) the most important rite in ancient Judaism: the Templar ritual. In my opinion, it is only barely capable of strengthening them, as access to the pronunciation of the previously unknown divine name is an act that is explicitly described as being open to everyone, at least in principle. By allowing access to the techniques of pronouncing the letters of the divine names to people who are not priests, and by ignoring the restriction of such a use to special occasions as the Rabbinic rituals do, Abulafia undermines the efficacy of the more mundane rituals whose mystical efficacy is conceived as less evident, unlike the par-

27 See also Abulafia's treatise preserved in Ms. Firenze, Laurenziana, Plut. II. 48, fols. 87b-88a and 92ab, where the high priest is again described in terms of ecstatic Kabbalah. See also Idel, Messianic Mystics, 194-97, and Sagerman, The Serpent Kills, 154-55. 
amount importance of the Rabbinic commandments in most other forms of Kabbalah.

In a way, Abulafia articulates a detailed type of technique or ritual of his own that has several slightly different variants in his various handbooks. One of his most influential expressions of these techniques can be found in Or ha-Śekhel. This ritual or technique implicitly supersedes the other, traditional rituals and is intended for younger people through the effective way in which they bring them as close as possible to the cosmic intellect. ${ }^{28}$ From his point of view, this is the universal religion and the language and script that are of supreme religious importance for the human species are found within the human spirit. However, Abulafia hardly dared to formulate his intention in a more explicit manner, given the persecutions that could result from such a radical approach, and indeed, persecutions seemed to haunt him throughout his career. Even prophecy, related as it is to imaginative power, speech, images, and writing, constitutes a lower form of activity in comparison to the much purer state achieved by the act of universalisation, which assumes a perfect form of intellection and the state of being with God alone, a form of theosis. ${ }^{29}$

Abulafia interprets the parable and the meaning of the pearl in terms that reflect his own messianic mission, which has strong intellectual overtones that transcend the historical religions. Not being interested in the question of which of the three historical religions is the true one, as in the ordinary version of the three rings parable, he proposes another, competing alternative which transcends the particular religions. He understood the highest form of religious life as a matter of inner development that is conceived as moving from a low form of cognition/connection to higher forms thereof and then the effacement (not the integration) of the lower in order to be able to attain the higher. This process should also be understood as referring to historical religions that emerged from the descent of the influx of the cosmic universal intellect and its transformation into the imaginative representations that include the conventionally established languages and institutional structures that constitute these religions. Their return to the universal status in the ideal situation means the

28 I dare to disagree with Elliot Wolfson's insistence, expressed in many places in his studies, as to the hypernomian nature of Abulafia's Kabbalah. In his opinion, the importance of the actual performance of the commandments for attaining the ideal experience is upheld by Abulafia and his techniques enforce the status of Rabbinic ritual. See, for example, Wolfson, Abraham Abulafia, 204-9 and 222-23; Wolfson, Venturing Beyond, 186-284; as well as its reverberations in Sagerman, The Serpent Kills, 5, note 8, 109, 122, note 44. In this context, see my different opinion in "The Kabbalistic Interpretations of the Secret of Incest in Early Kabbalah,” 158-59. In Or ha-Śekhel, 25, the Kabbalist envisions the performance of the commandments as preserving some form of social or psychological order whose existence facilitates the emergence of the conditions that allow for the attainment of the comprehension of God. On commandments as a political issue, see two passages from Oșar 'Eden Ganuz, 1:3, 121, 123.

29 See the important passage from Hayyei ha-'Olam ha-Ba', 197, which is discussed in my Studies in Ecstatic Kabbalah, 19-20; the passage from the commentary on Sefer ha-Melis, translated above, in chapter 8 note 66; and the passage from Sitrei Torah, 188, translated in chapter 21 note 289 above. 
transcendence of the specifics of their corporeal, emotional, or imaginative manifestations.

However, while describing the more general events that generated collective religious phenomena, for Abulafia, the most central narrative is the third one, which means not just privileging the experience of the individual elite as such, but also his own spiritual processes that are conducive to it. In fact, we know much about his life because of the importance he attributed to certain details of it; he interpreted some of the events that had happened to him as being meaningful for his message. It is an interesting enterprise to address Abulafia's personal secrets, which are to be added to the secrets of the Torah and the secrets of the Guide and which are presumably part of the eschatological secrets. ${ }^{30}$

This is one of the major discrepancies between Abulafia and all the other thirteenth-century Kabbalists: his personality is related to messianic secrets, his itinerant career is strongly related to the need to disseminate these secrets, and he was rejected because of them. This ultimate concern about saving others is missing in other Kabbalists, who were more concerned with improving the inner structure of the divine world. From this point of view, Abulafia attempted to continue Maimonides's mentalistic reform, assuming that a new and final stage of the revelation of the secrets was possible given the imminence of redemption.

Meanwhile, given the inaccurate understanding of the intellectual cosmos, each of the historical religions accuses the others of being idolatrous, as one of the followers of Abulafia's Kabbalah claimed, and such a statement puts the Judaism of his time in the same category as all the other historical religions. ${ }^{31}$ Though proclaiming the superiority of Judaism in many places in his writings, Abulafia nevertheless radically reinterprets the nature of this superiority by claiming that it is related less to God's premeditated choice of a specific nation as an organic unit, made solely on genetic or Halakhic grounds, ${ }^{32}$ than it is to intellectual processes and to combinations of letters. ${ }^{33}$ In other words, Abulafia's elitist Judaism has little to do with the much more democratic Rabbinic form of Judaism.

30 See Sitrei Torah, 16-17.

31 See the passage from the anonymous Sefer Ner Elohim, Ms. Munich, 10, fols. 156b-157a, a book whose views are close to those of Abulafia and which was translated in Idel, Studies in Ecstatic Kabbalah, 57, note 22. Compare also to Abulafia's Mafteah ha-Ra'ayon, 44-45, where he deconstructs the concept of a Jewish nation that is unified by the same beliefs. Unfortunately, the unique manuscript of this work is truncated in quite a sensitive part of the discussion, perhaps because of Abulafia's sharp critique of "Judaism." Meanwhile I identified another manuscript and will discuss the whole issue elsewhere.

32 See, for example, Hayyei ha-Nefeš, 5, where he speaks about the oblivion of the knowledge of God or his name in the present: אשר היה זר מאד מכל אומתינו היחידה הבחירה מהשם בימים הטובים ההם הקדמונים. 33 On Abulafia's interpretation of the meaning of Judaism as confessing the name of God without mentioning any other criterion, see the various texts presented in Idel, "A Unique Manuscript," $20-23$. 
Abulafia's identity as a Jew was less related to the Rabbinic criteria and thus less endangered by other religious options such as historical Christianity, as Sagerman's psychoanalytic approach to him stipulates. From his boastings about being a prophet and Messiah, where he sometimes implies that he is even higher than Moses, it is difficult to extrapolate a feeling of insecurity as to his Jewish identity as he understood it. At the same time, let me clarify, I do not assume that Abulafia was a predecessor of modern ecumenical dialogues or of scholars' assumptions that there is one universal truth behind the external forms of the different historical religions or the variegated forms of mysticism.

Abulafia believed that he was the founder of an old-new religion that possessed the true meaning of the Hebrew Bible; arbitrary as his exegesis was, the nature of this religion transcended the particularities of the historical religions and could, given the natural/intellectual character of his religiosity, in principle be embraced by everyone. Though philologically speaking he was influenced by both types of Christianity (Orthodox and Catholic) as well as by the Islamic falāsifah, he presents his revelation as original. Such a presentation consists in his strong reinterpretation of central topics related to particularism in traditional Judaism in a more natural and universal manner.

The esoteric meaning of the "choice," which has been discussed above in chapter 18 and below in Appendix A, is a paramount issue in Abulafia's esotericism, and only by understanding its natural significance-namely, that some things are inherently better than others-can we also understand other major issues in his thought. Messianism is therefore less a divine voluntary intervention in history, as is the case in traditional Judaism, but rather the result of intellectual activity initiated by an individual, which means a natural type of activity. Even the national redemption that concerns the Jewish people is described by Abulafia in a natural manner-in political terms $\mathrm{s}^{34}$ and in some other cases in astronomical terms-but hardly as the forceful intervention of the divinity in the course of events, as is the case in the popular apocalyptic texts and in many elite descriptions of messianism.

To summarise the point under scrutiny here: the horizontal, national messianism as a popular and exoteric dimension found in Jewish popular literature and in the historical interpretation of the parable on the one hand and the vertical, individual, esoteric redemption found in this context on the other represent diverging messages that are related to the parable of the pearl and are presented in an intertwined manner in the same text. Nevertheless, according to Abulafia, contradicting as these two narratives may be from the phenomenological point of view, they may eventually converge when a person who believes that he has already redeemed himself takes over the responsibility or the mission of restructuring religion. This is the case 
with the ecstatic Kabbalist, ${ }^{35}$ who believed that he was the son in the parable and, so I assume, also the current possessor of the pearl. ${ }^{36}$

The certainty generated by presumably strong mystical experiences, triggered by accelerated forms of bodily, vocal, and mental activities, may have convinced Abulafia that he could reach the status of a different species from the human one, ${ }^{37}$ an experience that explains his radical attitude as well as the negative reactions to his views. ${ }^{38}$ It is this type of transformation through processes leading to spiritual simplification and universalisation that constitutes the ultimate ideal of Abulafia's mysticism. His writings should be understood as an attempt to attain the pure state of noetic union with the divine realm or divinisation by an act of intellection, a state that he conceived as being higher than prophecy. ${ }^{39}$ Interestingly enough, the possibility of attaining such extreme experiences was not envisioned to be a secret, despite Maimonides's reticence to allow it as part of intellectual life.

However, unlike the philosophers, and most of the theosophical-theurgical Kabbalists, who capitalised on the Rabbinic commandments as modes for arriving at a higher type of religious experience, the ecstatic Kabbalist proposed several new and precise techniques that were contrived from a variety of sources and were intended to assist the practitioner to achieve the highest noetic goals. He was not only interested in using philosophical allegorisations in order to solve theological misinterpretations, as Maimonides and most of the Maimonideans were, but much more so in an articulation of an interiorised type of religiosity that could be attained in a short time by resorting to techniques that neither Maimonides and his followers nor most of the other Kabbalists would accept. ${ }^{40}$ Abulafia was more interested in a rather drastic type of human change, while the Maimonideans, like Maimonides himself, were

35 It should be mentioned that in some Midrashic tales, the biblical Abraham was described as possessing a pearl that was capable of healing whoever saw it. See, for example, BT, Babba' Batra', fol. 16b. Is there an affinity between the two proper names, that of Abulafia and that of Abraham who possessed a pearl?

36 See the passage cited above in chapter 20 note 229; see also Idel, Language, Torah, and Hermeneutics, 124.

37 See the passage from his commentary on the prophetic book Sefer ha-Melis, written in Messina in 1282, translated above in chapter 8 note 66.

38 Later on, Abulafia was persecuted by the most important figure in the camp of Sephardi Rabbinic leadership: Rabbi Solomon ibn Adret. See my "The Rashba and Abraham Abulafia."

39 See Abulafia's resort to concepts of simplification and unity in Hayyei ha-Nefeš, 20, and Or haSekhel, 41. Compare to the divinisation of the soul in Rabbi Judah ha-Levi's Kuzari, 1:103, and Rabbi Azriel of Gerone's appropriation of this view in his Commentary on the Talmudic Legends, ed. Isaiah Tishby (Jerusalem: Mekize Nirdamim, 1945), 14.

40 For the analyses of some of Abulafia's texts as part of a larger phenomenon of an "inner religion," see Ron Margolin, Inner Religion: The Phenomenology of Inner Religious Life and Its Manifestation in Jewish Sources (From the Bible to Hasidic Texts) [Hebrew] (Ramat-Gan: Shalom Hartman Institute, 2011), 208-11, 257-60, 314-19, 402, 405-6. In 269-71, Margolin finds a similarity between Abulafia's interiorised interpretation and a Zoharic passage which speaks about the parallelism between human states and the various events on high, the latter dimension being absent in Abulafia's writings. 
concerned with a longer form of development of the human spirit that was less related to ecstatic experience.

To summarise this point: though Abulafia followed Maimonides's allegorical exegetical technique, he was inclined to generate a narrative that implicitly pointed not only to inner processes, but also to his own experiences and to his special role in teaching a new spiritual message. These two points were connected to esotericism and sometimes remained only implicitly. However, the interiorisation and individualisation of the religious experience do not also mean its democratisation, as we have amply seen above.

\section{Individual versus Collective Experiences}

Let me turn now to another dimension of the experiences Abulafia described. In all the handbooks which explain his techniques, the instructions are very clear: the aspirant should be alone in a special chamber when using them. ${ }^{41}$ This situation is corroborated by the descriptions of the mystical exercises as found in Rabbi Nathan ben Sa'adyah Har'ar's book. ${ }^{42}$ The master is never described as accompanying the aspirant in the secluded room when he practises the techniques, or as someone who surveys the aspirant as he performs the technique or reaches an ecstatic experience.

This individualistic approach is also evident in Abulafia's understanding of redemption as a supremely individual experience, as part of the third narrative. On the other hand, no traces of descriptions or assumptions of collective experiences are found in ecstatic Kabbalah as there are, for example, in Sufism. Surprisingly enough, this absence becomes more evident when he describes some groups of students studying with him at the same time, also providing their names, unlike the rather evasive identity of the Kabbalists who co-operated in the production of the Zoharic corpus, an issue to be addressed immediately below in this chapter. ${ }^{43}$

On the other hand, the contemporary Zoharic descriptions of raptures are often related to the unique status of the master, the legendary Rabbi Simon bar Yochai, his special achievements, his life, and his death. ${ }^{44}$ In other words, his presence and preaching and his extraordinary revelations of secrets regarding the supernal world are part and parcel of triggering the mystical experience or rapture, or at least intensifying it. It is his magnetic personality that is imagined to constitute the pillar of the group composed of his students.

41 See Idel, Studies in Ecstatic Kabbalah, 103-19, 122-25, and Idel, The Mystical Experience, 37-41, 144.

42 Le Porte della Giustizia, 478-79; Scholem, Major Trends in Jewish Mysticism, 150-51.

43 See below. 273-76.

44 On his special status in the Zohar and Jewish mysticism under its influence, see Yehuda Liebes, Studies in the Zohar, trans. Arnold Schwartz, Stephanie Nakache, and Penina Peli (Albany, NY: SUNY Press, 1988), 1-84, and Hellner-Eshed, A River Flows from Eden, 31-51, 330. 
This stark divergence sharply differentiates between the two types of Kabbalistic literature. Nevertheless, the two literatures share the same background of encounters between Sephardi and Ashkenazi masters, the latter bringing to Spain from the $1260 \mathrm{~s}$ onwards not only an interest in pneumatic experiences, but also a resort to linguistic techniques, understood mystically by Abulafia and magically by other Kabbalists in Castile. This common denominator requires a more elaborate analysis than can be undertaken within this framework.

The emphasis on the importance of loneliness and seclusion in ecstatic Kabbalah when approaching the divine and during the prophetic experience should be compared to what happened in the same period with the Maimonideans and the theosophical Kabbalists: no individual who claimed to be a prophet or who was regarded as a prophet by others is known to have belonged to these two schools in Abulafia's lifetime. The only two examples we know about in Castile, Rabbi Nissim ben Abraham, the youth from Avila, and Rabbi Samuel the Prophet, are not known for being Kabbalists or philosophers, and in any case, they have no extant theosophical writings.

As seen above, Abulafia's attitude to Rabbinic myths is sharply negative, an attitude that opposes the more welcoming approach of the theosophical Kabbalists, especially within the Zoharic corpus, to this layer of Rabbinic literature. Such a welcoming approach contains no parallels to what we have seen above in Abulafia's writings.

These divergences notwithstanding, claims have recently been made as to the prophetic nature of Rabbi Moses de Leon's and Rabbi Joseph Gikatilla's expressions. Charles Mopsik claims they were influenced by the prophetic ambience that Abulafia had created. ${ }^{45}$ On the other hand, Elliot Wolfson and others claim that there are ec-

45 Rabbi Moses de Leon's Sefer Šeqel ha-Qodeš [Hebrew], ed. Charles Mopsik (Los Angeles: Cherub Press, 1996), 6-8. I would claim something different: the prophetic mode that arrived from Ashkenaz, where the category of prophet was not problematic in the first half of the thirteenth century and influenced Abulafia, also triggered the Castilian Kabbalists to look for a more revelatory approach. See my "Incantations, Lists, and 'Gates of Sermons." We may see a common denominator in the sudden emergence of two schools of Kabbalah at the same time in Spain (the ecstatic and the Zoharic) as the appropriation of different types of linguistic techniques that liberated the more doctrinal approach found in Maimonideanism and in the earlier Spanish Kabbalah and triggered these different forms of creativity. For Pedaya's attribution of the central role of Abulafia's messianism and calculations, as well as his disappearance and disappointment due to the failure of his messianic mission in Castilian Kabbalah, see "The Sixth Millennium," 68, 73-75, 82, 85, 91, 96, where she assumes that the channel of transmission of Abulafia's messianism was Rabbi Joseph Gikatilla, Abulafia's former student, whose relationship with Abulafia was discussed above. I wonder, however, where Gikatilla expressed anything about a type of messianism or eschatological calculations similar to those of his former teacher, either in his printed or manuscript writings. I would say, if at all, that he was much closer to Abulafia's concepts of spiritual or individual redemption, what I call the third narrative or register, than to his historical eschatology, which does not occur in Gikatilla's writings. However, except for two brief mentions of his first name, which were immediately eliminated from the final form of Ginnat Egoz, written in 1274, Abulafia's name never occurs throughout his many writings 
static experiences in the Zoharic literature, claims that soften the gap between Abulafia's ecstatic Kabbalah and theosophical-theurgical Kabbalah. ${ }^{46}$

The first claim has already been addressed by Yehuda Liebes. ${ }^{47}$ I see no reason to change my opinion because of the brief references that Mopsik deals with that do not describe either techniques or detailed forms of general experiences and contain nothing similar to what is found in Abulafia's writings. In a small number of phrases that were adduced to this effect, de Leon and Gikatilla used expressions that point to some form of spiritual arousal, but no more-such terms can be found in many writings in the Middle Ages. The contents of their many books, however, point in quite a different direction from that of authors driven by prophetic or ecstatic experiences.

However, what is of capital importance from my point of view is they were neither called prophets by others nor did they claim to be so. This is not just a matter of an absence of hidden experiences, but of how they perceived themselves and were perceived by others. Against the background of the Rabbinic claim about the cessation of prophecy, de Leon and Gikatilla did not rebel or even try to question the prevalent traditional opinion on the topic. To have a mystical experience is one story; to claim that it is prophetic or ecstatic is quite a different one. We can see this see quite clearly from the writings of Rabbi Isaac of Acre, who is not shy about discussing his various mystical experiences; however, despite his acquaintance with ecstatic Kabbalah, he categorically denies that he is a prophet. ${ }^{48}$ In any case, in Rabbi Solomon ibn Adret's famous responsum, he enumerates some extraordinary pneumatic experiences in his lifetime among the Jews in Europe, but there is no mention of any Kabbalist except Abraham Abulafia.

Let me point out that the most important statement about prophecy as a possible everyday experience was formulated in Castile only two generations later in a famous Halakhic compendium written by an Ashkenazi Rabbi, Rabbi Jacob ben Asher. Dealing with the Halakhic instructions related to prayer, he writes:

Let him think as if the Šekhinah were standing before him, as it is said "I always set God before me," ${ }^{49}$ and he should arouse the kawannah and erase all annoying thoughts so that his thought and intention will remain pure during his prayer [...]. It is obligatory to direct one's thought because for Him, thought is tantamount to speech [...] and the pious ones and the men of [good]

(see also p. 76 above). In any case, the possible link between Abulafia's attempt to meet the pope and a passage in the Zohar, in both cases depicted as having some form of messianic valence, is, surprisingly enough, not mentioned by Pedaya at all. See the discussions by Adolph Jellinek and me to this effect that are referenced in Idel, Messianic Mystics, 121-24. See also chapter 19 note 225 above.

46 Elliot R. Wolfson, "Forms of Visionary Ascent as Ecstatic Experience in the Zoharic Literature," in Gershom Scholem's Major Trends in Jewish Mysticism 50 Years After, eds. Peter Schäfer and Joseph Dan (Tübingen: Mohr Siebeck, 1993): 219-20, 227, 234-35, where he claims that the Zoharic circle already existed.

47 “Review Essay: Charles Mopsik, Rabbi Moses de Leon’s Sefer Šeqel ha-Qodeš” [Hebrew], Kabbalah 2 (1997): 284-85.

48 See Scholem, On the Mystical Shape, 227-28.

49 Psalm 16:8. 
deeds were concentrating their thought and directing their prayer to such an extent that they reached a [state of] divestment of their corporeality and a strengthening of their intellective spirit so that they would reach [a state] close to prophecy. ${ }^{50}$

However, despite the prophetic moment ben Asher inserted, no serious scholar would regard his book as part of a prophetic or ecstatic literature. Ecstasy or prophecy is one thing; ecstatic or prophetic Kabbalah as a more elaborated conceptual approach represented as a literature is another.

Insofar as the second claim as to the alleged ecstatic experiences in the Zoharic literature is concerned, the situation is much more complex. Let me begin with the terminological problem. Unlike prophecy, "ecstasy" is a term imposed by scholars, and as such, it needs to be defined. I have attempted to qualify the use of ecstasy by resorting to the category of "intense ecstasy" in the case of Abulafia's experience, following Marganita Laski, ${ }^{51}$ in order to distinguish it from contemplative forms or from the "contained experience" of the Zoharic companions, as Hellner-Eshed describes it. ${ }^{52}$ Elsewhere, I have proposed seeing ecstasy as a constant in human religious experience. ${ }^{53}$ More recently, I distinguished between different categories of ecstatic language in various layers of Jewish mysticism. ${ }^{54}$

My assumption is not that ecstatic Kabbalah is the only type of Kabbalistic school where ecstasies occur, but that that ecstasy is "the essential purpose of ecstatic Kabbalah," as well as the use of "techniques for its attainment." ${ }^{55}$ This means that the centrality and intensity of ecstatic experiences and the existence of specific techniques for achieving them are criteria for describing a given body of literature as ecstatic, not just relying on harbouring some types of rapture related to the performance of Rabbinical commandments or exegetical practices that a scholar decides to call "ecstasies." This is the reason why I use the term "core" in this context in order to avoid too harsh a separation between the different Kabbalistic schools. ${ }^{56}$

My approach should therefore be understood as a search for the general characteristics of certain schools or models without assuming an absolute separation between them. This approach has been judiciously understood in Melila Hellner-

50 Tur, Orah Hayyim, 98. For the huge impact of this passage, see Raphael J. Zwi Werblowsky, Joseph Karo: Lawyer and Mystic (Philadelphia: Jewish Publication Society, 1977), 61-62, and Aryeh Kaplan, Meditation and Kabbalah (York Beach: Weiser Books, 1982), 283-84, who pointed out some sources and influences for this passage. See especially a text printed in Talmidei Rabbenu Yonah, on Berakhot 5, which is quoted in Heschel, Prophetic Inspiration after the Prophets, 26-27; Idel, Studies in Ecstatic Kabbalah, 163-64, note 136; and Idel, Hasidism: Between Ecstasy and Magic, 64-65.

51 See Idel, The Mystical Experience, 40.

52 Hellner-Eshed, A River Flows from Eden, 326.

53 Idel, Hasidism: Between Ecstasy and Magic, 53-54, 56.

54 Moshe Idel, "On the Language of Ecstatic Experiences in Jewish Mysticism," in Religionen-Die Religiöse Erfahrung (Religions-The Religious Experience), eds. Matthias Riedl and Tilo Schabert (Würzburg: Verlag Königshausen \& Neumann, 2008): 43-84.

55 Idel, The Mystical Experience, 8.

56 Idel, Kabbalah: New Perspectives, xviii. 
Eshed's discussions of Zoharic ecstasy as they compare to those of Abulafia. ${ }^{57}$ Without some definitions, qualifications, or distinctions, there is no great gain from using terms such as "genuine ecstasy" 58 or "profoundly ecstatic" experiences that reflect a scholar's opinion on the Zoharic literature. ${ }^{59}$

As becomes more and more evident in scholarship, the first layers of Zoharic literature, which do not include the two later treatises Tiqqunei Zohar and Ra 'aya' Meheimna', do not constitute the work of a single Kabbalist, as scholars thought when it was attributed to Rabbi Moses de Leon, and the question that is increasingly being discussed is whether it is a collective work of a group of co-operating Kabbalists, ${ }^{60} \mathrm{a}$ work of different groups, ${ }^{61}$ or merely uncoordinated reworkings of a variety of Aramaic texts that fell into the Kabbalists' hands. ${ }^{62}$

Let me reiterate the approach that I suggested before the emergence of these proposals:

By the 1270s, the province of Castile had become an important meeting centre of Kabbalists [...]. We can therefore regard Castile between 1270-1290 as a meeting point for all the major trends within Kabbalah [...]. These two decades witness the final steps in most of the older Kabbalistic traditions and the birth of a more complex approach to Kabbalah as a discipline encompassing previously discreet trends of thought. This new approach, mostly represented by three Kabbalists-Gikatilla, de Leon, and Joseph of Hamadan-as well as by the Zohar, constitutes what I propose to call the "innovative Kabbalah" in Spain. [...]. Now the time had come when the Kabbalists had learned the motifs of this mysterious melody and were able to compose novel variations, elaborating upon older motifs and creating new ones. This new work was the Zohar, which constituted both the first outpouring and the climax of Kabbalistic symbolic creation. ${ }^{63}$

This means that all the trends found in Kabbalah, including the ecstatic one, met and confronted each other in Castile, and in principle, there is no problem with assuming its influence on some of the developments in the region, including the Zoharic literature. After all, as mentioned above, Abulafia taught some Kabbalists in Castile. However, such a view does not preclude the emergence of a phenomenologically

57 Hellner-Eshed, A River Flows from Eden, 314-16, 318.

58 Through a Speculum That Shines, 330. In my opinion, "genuine" is a rather doubtful category, scholarly speaking.

59 Wolfson, "Forms of Visionary Ascent," 234-35. For an additional contraposition of the mystical (Maimonidean) versus the mythical (Zoharic) approach, see Lorberbaum, Dazzled by Beauty, 2628; this is an opposition that fits Abulafia's propensity for de-mythologisation versus the Zoharic propensity for mythologisation.

60 This is the theory of Yehuda Liebes, Studies in the Zohar, 85-138, and, more recently, Elliot Wolfson, who claims to have detected the description of such a group and has printed a Kabbalistic treatise emanating from it. See chapter 25 note 64 below.

61 This is the theory of Ronit Meroz, "Zoharic Narratives and Their Adaptations," Hispania Judaica 3 (2000): 3-63.

62 Daniel Abrams, Kabbalistic Manuscripts and Textual Theory (Jerusalem: Magnes Press, 2011), 224428.

63 See Idel, Kabbalah: New Perspectives, 211-13, 215. 
different type of Kabbalah in Castile after Abulafia left the Iberian Peninsula, which is my claim.

Moreover, the note attached to my considerations cited above reads as follows:

This view of the Zohar as the zenith of a certain process taking place over the two decades 12701290 is not, however, identical with the view that this work is the exclusive composition of Rabbi Moses de Leon, as assumed by Scholem or Tishby. I believe that older elements, including theosophical views, symbols and perhaps also shorter compositions, were merged into this Kabbalistic oeuvre which heavily benefited from the nascent free symbolism. ${ }^{64}$

In my opinion, these are the facts that are of primary relevance as one of the most important intellectual backgrounds for the emergence of the Zoharic literature, and all the later hypotheses still need more concrete evidence in order to become full-fledged theses. In any case, by now, all the serious scholars in the field do not assume a homogenous Kabbalistic approach within the Zohar. In other words, the Zoharic literature incorporates a variety of views found in Kabbalistic trends that are different from each other and that differ from Abulafia's corpus, which was written by a single author and is more coherent despite his conceptual fluidity.

However, from the specific point of view that concerns the comparisons to Abulafia, let me refer to three major differences that distinguish the two Kabbalistic schools insofar as the experiential aspects are concerned: 1) the experiences described in the Zohar are always collective and not individual, 2) they are described

64 Idel, Kabbalah: New Perspectives, 380, note 66, and, in general, 211-15, as well as my introduction to Efraim Gottlieb, ed., The Hebrew Writings of the Author of Tiqqunei Zohar and Ra'aya' Meheimna' [Hebrew] (Jerusalem: Israeli Academy for Sciences and Humanities, 2003), 30; Idel, Ascensions on High, 125; and Idel, "Moses Gaster on Jewish Mysticism and the Book of the Zohar," 122, note 47. The quoted statement, as well as others, points to a complex attitude towards what "innovative" means in matters of Kabbalah. My views of the Zohar have been judiciously summarised by Daniel Abrams, "The Invention of the Zohar as a Book: On the Assumptions and Expectations of the Kabbalists and Modern Scholars," Kabbalah 19 (2009): 56-61; Abrams, Kabbalistic Manuscripts and Textual Theory, 295-333. Compare, however, the distorted, in fact inverted, manner in which my views on Zoharic hermeneutics, which I have called innovative Kabbalah, are presented in the same volume of Kabbalah (19) by Wolfson, "The Anonymous Chapters of the Elderly Master of Secrets," 169-71. His "own" view on the topic of hermeneutics is actually much more similar to what I described in the passage from Kabbalah: New Perspectives, 380 that was cited above. Needless to say, in the case of Abraham Abulafia, another main representative of what I called innovative Kabbalah, I emphasised the important contribution of earlier Ashkenazi elements in his hermeneutics. However, I do not share his view that we have evidence of what he calls "the early activity of the Zoharic Circle" in the Kabbalistic text he printed. I have expressed my view as to the composition of the Gates of the Elderly Man in the last decade of the thirteenth century in some of my studies. Since more material belonging to this circle is extant in manuscripts and has not been dealt with in scholarship before, it is wiser to postpone a detailed discussion of Wolfson's argument as to the alleged "circle of the Zohar" as if it is reflected in the details found in this treatise. Meanwhile, see also the critical view of Yehuda Liebes, The Cult of the Dawn: The Attitude of the Zohar towards Idolatry [Hebrew] (Jerusalem: Carmel, 2011), 91, note 31, towards Wolfson's hypothesis that the Zohar was written in this specific circle, if it existed at all in reality. 
as involving the Kabbalists' souls and not their intellects, as is the case with Abulafia, and 3) they are presented as experiences of the past, of ancient Rabbinic figures, of a way of thought that negates the continuation of prophecy, though some form of ecstasy is found in Rabbinic literature in the context of prayer. ${ }^{65}$ Again, the absence of the term "prophet" is not just a matter of terminology, but reflects the main gist of Zoharic literature, which strives to present itself as the deeper layer of the Rabbinic mentality, an approach that does not easily lend itself to claims related to prophecy. ${ }^{66}$ Moreover, Abulafia's emphasis on individual experiences is related to the fact that he mentions his name in his writings, which is not the case in the Zoharic literature, or in many other theosophical-theurgical writings that resort to pseudo-epigraphic techniques or anonymity.

Let us turn now to the recent scholarly claim of the existence of ecstasy in the two schools: as I have proposed elsewhere, this claim would require a distinction between mere occurrences of moments that can be described as ecstatic in a literature that deals with a variety of other topics, including moments of rapture, and a literature that as its main religious aim is devoted to reaching ecstatic experiences and defining them as achievable by specific paths initiated by the mystic. ${ }^{67}$ In principle, the claims as to the existence of ecstatic moments in the Zoharic literature are not new. Scholem formulated them in a cogent manner: "It is a significant fact that the most famous and influential book of our mystical literature, the Zohar, has little use of ecstasy." 68 I believe that this diagnosis is correct.

However, my more general assumption is that ecstasy is certainly not the prerogative of one specific Kabbalistic school, as I formulate it: "The ecstatic element in Jewish mysticism is to be understood as an important constant, rather than the prerogative of a certain phase or school" 69 or "the quest for ecstasy [...] is part and parcel of a quest that was inherent in Jewish mysticism, much more outside Spain rather than in the Iberian Peninsula."70 In fact, I have compared the mystical elements in Abulafia and the Zohar in quite an explicit manner. ${ }^{71}$ However, while Abulafia's Kabbalah was explicitly intended to experience prophecy, in the Zoharic literature, this is not explicated as a distinct goal and it is quite probable that they occur sporadically, at least according to the claims made in the texts.

65 On the nexus between prayer and ecstasy in early Rabbinic literature, see Shlomo Na'eh, "Bore' Niv Śefatayyim,” Tarbiz 63 (1994): 185-218; Abraham Wolfish, “Ha-Tefillah ha-Šogeret,” Tarbiz 65 (1996): 301-14.

66 See Moshe Idel, "Lawyers and Mystics in Judaism: A Prolegomenon for a Study of Prophecy in Jewish Mysticism," in The Joseph and Gwendolyn Straus Institute Working Papers (New York: New York University, 2010): 3-42.

67 See Idel, “On the Language of Ecstatic Experiences in Jewish Mysticism,” 71-72.

68 Scholem, Major Trends in Jewish Mysticism, 123.

69 Idel, “The Contribution of Abraham Abulafia’s Kabbalah,” 129.

70 Idel, 128.

71 Idel, Hasidism: Between Ecstasy and Magic, 97-98. 
The Zoharic moments of rapture occur as part of homiletic discussions in a group or circle; whether this is imaginary or real is less important. ${ }^{72}$ This is part of an interpretive symbolic-mythic approach to the biblical and Midrashic materials. ${ }^{73}$ As Mopsik duly puts it, the Zohar is a Midrash on a Midrash. ${ }^{74}$ It includes efforts to deepen the mythical aspects of the canonical texts by elaborating on the fabric of the texts, not by arbitrarily deconstructing and then reconstructing them. ${ }^{75}$ Moreover, as seen above, Abulafia's deconstruction of the texts is not only a matter of a radical exegetical approach, but one that centres the development of the individual, that consciously infuses new meanings that do not come from a project or group focused on the fate of a nation, as is the case in the Zohar.

Abulafia does not choose imaginary ancient Rabbis promenading in imaginary geographical areas of the Land of Israel or a group studying in a cave to be his protagonists, but rather a Kabbalist who is capable of allegorically understanding his or others' experiences as a continuation of those of the biblical figures, or even a transcendence of them. Abulafia writes mainly about himself for his specific-and in many cases, younger-disciples; in some cases, we know their names and writings, their locale, and rather precise dates. Though he was a Neo-Aristotelian thinker, the background of Abulafia's experiences is not the peripatetic walks of the ancient philosophers in nature as is the case of some of the compositions from the Zoharic circle, ${ }^{76}$ but a secluded room found, so I assume, in a populated area.

However, it should be emphasised that some of Abulafia's descriptions of the mystical experience, especially those in the prophetic books, reflect what he claims were his experiences and can be described as ego-documents. Let me give just one example: "[...] So also the Agent Intellect, ${ }^{77}$ and I testify taking heaven and earth as my witnesses, that it [the Agent Intellect] taught me in such a way [...] and the speech that comes from it is according to the intellectual comprehension." "78 This resort to first-person revelations is rather rare outside the school of ecstatic Kabbalah.

This confession should be understood in the context of Abulafia's understanding of Kabbalah as a revelation stemming from the Agent Intellect in a manner that is more profound than the philosophical knowledge that stems from the very same source. ${ }^{79}$ Unlike the expansion of consciousness in the various descriptions of the

72 Hellner-Eshed, A River Flows from Eden, 107-10.

73 See Hellner-Eshed, 331-32, 334.

74 See Mopsik, Chemins de la cabale, 168-70.

75 See Idel, Language, Torah, and Hermeneutics, xiii-xv; compare also to Hellner-Eshed, A River Flows from Eden, 330-32, and Mopsik, Chemins de la cabale, 229-30.

76 Hellner-Eshed, A River Flows from Eden, 111-20.

77 Earlier, he describes this intellect functioning as a teacher.

78 Mafteah ha-Šemot, 147-48:

חשכל.... השכל.

For God speaking with prophets without mention of visions, see Sitrei Torah, 91.

79 Mafteah ha-Hokhmot, 56-57: 
experiences of the companions of the Zoharic circle, which did not annihilate their personalities, but nevertheless maintained an intimate contact with the supreme realm, ${ }^{80}$ Abulafia is concerned with a mystical union of the intellect that may culminate in a fusion between it and the supernal intellectual realm.

Nor is Abulafia concerned with theosophy and theurgy that sometimes puts the complex divine structure at the centre of its sermons, as the Zoharic literature does. It suffices to read the most theological Zoharic compositions, Sifra' di-Seni 'uta' and the Iddrot, in order to understand how far the Zoharic world is from that of Abulafia. The composite nature of the divinity with its various manifestations, the ten sefirot or the various parșufim, is nevertheless conceived as constituting one unified dynamic theological unit and is also reflected by the confraternity, by the entire people of Israel, which are such composite entities. Also, from this point of view, the main bulk of the Zoharic literature continues the Rabbinic-Midrashic mode of creativity that operated with a variety of ideas which were in tension with one another, but which were nevertheless accepted as part of a more comprehensive structure.

Those are two quite different forms of imaginaire that stem from different profound structures, distinguished from each other terminologically, structurally, and conceptually. They also determined their different fates in the history of Jewish mysticism: the Zoharic imaginaire was drawing from the Rabbinic universe, which was interpreted mythically and sometimes symbolically, ${ }^{81}$ while the Abulafian imaginaire drew from the Greek philosophical universe and operated in what I have called an allegorical-spiritualistic manner. The former is dramatically nomian and its protagonists are famous Rabbis; the latter is anomian, articulated by a person who is most often writing for individuals who belong to the secondary elite and who criticises contemporary Rabbis rather than emulates them. These are the reasons for the huge success of the Zoharic corpus in the history of Jewish mysticism in comparison to the Abulafian Kabbalah that remained a secondary and elitist school.

In a way, the two main Kabbalistic schools that emerged in the last quarter of the thirteenth century in Europe represent two different modes of religiosity, parallel, mutatis mutandis, to what Strauss and Eliade advocated: the individual versus the group in the case of the former, and the group as the basic religious unit that thrives by developing a mythical type of consciousness in the case of the latter. Let me emphasise the historical dimension of the two modes: mythical elements are found in Greek myths, but the Greek philosophers in late antiquity either ignored them or allegorised them. This also happened in late antique Judaism in the case of Philo of

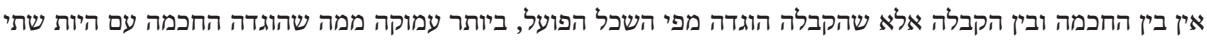

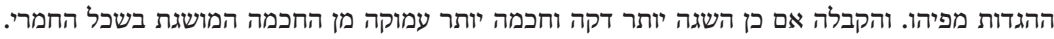
See Scholem, Major Trends in Jewish Mysticism, 143-44.

80 Hellner-Eshed, A River Flows from Eden, 325.

81 See Yehuda Liebes, "Myth vs. Symbol in the Zohar and Lurianic Kabbalah,” in Essential Papers on Kabbalah, ed. Lawrence Fine (New York: New York University Press, 1995): 212-42. 
Alexandria, ${ }^{82}$ but the philosophical-allegorical approach did not make its way to Rabbinic Judaism, which continued to operate with many mythologumena. The adoption of this exegetical approach in the High Middle Ages, especially in ibn Gabirol, ibn Ezra, and Maimonides, prompted Abulafia's exegesis, with its proclivity towards the individual inner experience, triggered to use one of his techniques by his personal predilections.

While the theosophical-theurgical Kabbalists remythologised the Jewish texts and the meanings of the commandments, Abulafia, following Maimonides, strove to demythologise them. However, unlike the Great Eagle, Abulafia does so not only through a naturalist approach, but also and prominently by "mystifying" the sources, by claiming that the true meaning of the sources is to point to the ideal of prophecy, ecstasy, or unitive experiences. In short, the tension between the noetic interpretation and the mythical one that shapes the relationships between how Maimonides, the Maimonideans, and Abulafia understood reality and society and traditional Judaism (including theosophical-theurgical Kabbalah) are part of a much longer history; it also assumes a tension between the individual and the social. ${ }^{83}$

While in ecstatic Kabbalah the mystical experience is conceived as standing in itself, especially in the case of the mystical union, in the Zoharic Kabbalah, and I would say in theosophical-theurgical Kabbalah in general, the experience of adherence to the divine as a mystical experiment was thought to be followed by a theurgical operation. ${ }^{84}$ This means that when seen in a more holistic manner-namely, when incorporated into different conceptual structures-the same mystical phenomena, if we may speak about significant similarities in issues like these, are different since they are conjugated with different elements and thus generate different models. ${ }^{85}$

82 Maren R. Niehoff, Jewish Exegesis and Homeric Scholarship in Alexandria (Cambridge: Cambridge University Press, 2011).

83 See also Eric Voegelin, Anamnesis, ed. and trans. Gerhart Niemeyer (Columbia: University of Missouri Press, 1990), 185.

84 See Idel, Kabbalah: New Perspectives, xviii, 51-58, and Hellner-Eshed, A River Flows from Eden, 318. Compare to the quite similar view of Seth H. Brody, "Human Hands Dwell in Heavenly Heights: Worship and Mystical Experience in Thirteenth-Century Kabbalah” (PhD diss., University of Pennsylvania, 1991), and “'Human Hands Dwell in Heavenly Heights': Contemplative Ascent and Theurgic Power in Thirteenth-Century Kabbalah," in Mystics of the Book: Themes, Topics, and Typology, ed. Robert A. Herrera (New York: Peter Lang, 1993): 123-58. This more complex approach has also been more recently adopted in Haviva Pedaya, "Two Types of Ecstatic Experience in Hasidism” [Hebrew], Da'at 55 (2005): 81. She is apparently unaware of my methodological claims to this effect and asserts that I analysed isolated concepts by themselves and not their wider concatenation in the framework of broader models. See also her "The Besht, Rabbi Jacob Joseph of Polonnoye, and the Maggid of Mezeritch: Basic Lines for a Religious-Typological Approach” [Hebrew], Da'at (2000): 71. Compare also to the reference to the Gestalt-contexture in chapter 2 note 49 above as well as the gist of my study, Hasidism: Between Ecstasy and Magic.

85 See Idel, Hasidism: Between Ecstasy and Magic, 45-145. 
To be sure, I do not deny the mystical aspects of the theosophical-theurgical Kabbalists, as some scholars mistakenly assume, but I propose to see them as being essentially subordinated to another goal, the unification of the divine sphere or its reparation, tiqqun, which Abraham Maslow called "means-experience," that those Kabbalists conceived to be higher than adherence. Abulafia's experiences were target experiences that were, in many cases, conceived as the end of the mystical path. ${ }^{86}$ Therefore, discussions about the existence of ecstasy alone without first defining what a scholar means by this term and addressing their conceptual context are rather futile.

The two foci of Abulafia's ideal experiences should also be seen from another perspective. The revelations he describes gravitate around more than one basic vision: the mystic may see aggrandised letters or his own self conversing with the mystic during the experience, ${ }^{87}$ or a vision of a circle or globe, ${ }^{88}$ or, in other cases, a vision of the human form, an old man, standing for the Agent Intellect, ${ }^{89}$ or the revelation of the angel of Paradise. ${ }^{90}$ In some cases, some form of speech emerges from the mystic's mouth without an accompanying vision. ${ }^{91}$ This means that it would be erroneous to reduce Abulafia's descriptions to one single type of experience, although he refers in many cases to the phenomenon he calls prophecy. A variety of experiences that may all be regarded as mystical, some having ecstatic overtones, can also be found in the description of the experiences of Rabbi Nathan ben Sa'adyah. ${ }^{92}$ Therefore, the reduction of Abulafia to one type of experience, the ecstatic one, is just one step in identifying this alleged one type of experience as that allegedly found in the Zohar-another even more diversified type of Kabbalistic literature, as seen above. ${ }^{93}$

86 See also Idel, Hasidism: Between Ecstasy and Magic, 130, 169, 376, note 1.

87 See Appendix B note 81 below. This view is described in Scholem, The Kabbalah of Sefer ha-Temunah, 185, as some form of incarnation. It was also adopted by Wolfson, "Textual Flesh, Incarnation, and the Imaginal Body," who fails to mention Scholem's resort to the concept of incarnation in connection to Abulafia, though he refers to other discussions of Christianity in Abulafia that appear in Scholem's writings. See 195-96, note 24. However, what Abulafia means in these texts is the emergence of a configuration within the imagination of the mystic that has a form that differs from one case to another and that is not necessarily a human body, still less fleshly. This is the reason why I speak about "informment" rather than incarnation. See Idel, Ben, 60-61, 101, note 182, 278, 420, 451, and compare to Wolfson's cavalier rejoinder, "Textual Flesh, Incarnation, and the Imaginal Body,” 200, note 41. In any case, in order to understand Abulafia's mystical experiences, one should take into consideration the existence of several modes of revelation and not reduce the wide spectrum to one colour (the allegedly "incarnational" one) alone.

88 Idel, The Mystical Experience, 109-11.

89 Idel, 112-16.

90 See the Untitled Treatise, Ms. Firenze, Laurenziana, Plut. II, 48, fols. 69a, 71b, 89b-90a.

91 Idel, The Mystical Experience, 83-86.

92 See Le Porte della Giustizia, 478-79, and Scholem, Major Trends in Jewish Mysticism, 150-52.

93 See Hellner-Eshed, A River Flows from Eden, 318. Following Elliot Wolfson to a certain extent, Pedaya claims to know, on the grounds of sources unaccounted for or at least unknown to me, 
My rather different proposal is based on the importance of the distinction between various types of language in Jewish mysticism and their different conceptual sources and reflects different underlying types of experiences. This variety may even occur in different works by the same Kabbalist. ${ }^{94}$ It is only after a more elaborate picture of the varieties of mystical experiences in two vast corpora are recognised and analysed $^{95}$ that a comparison between them may be fruitful. The homogenisation of these corpora and then the homologisation between them in scholarship in the last two decades is too uncritical and, in any case, too conceptually vague to mean anything. In fact, it is a matter of manipulating terms that have not been sufficiently defined, and which are thus problematic, in order to make them academically fruitful.

In this context, let me point out that unlike the Maimonideans, Abulafia did not abandon his involvement with at least some part of society, though he was full of contempt for the vulgus. As Aviezer Ravitzky astutely remarks, Maimonides's followers adopted an elitist approach, rejecting their master's conceptual complexity, which combined philosophy with Halakhah in many of his writings. ${ }^{96}$ This is also the case with Averroes, who combined jurisdiction with philosophy. However, the devotion to the two types of activity did not enjoy a real continuation because the Maimonideans adopted a more contemplative approach influenced by ibn Bāğğah and ibn Tufayl. ${ }^{97}$ With all his emphasis on noetic activity, Abulafia was nevertheless more socially active than the other Maimonideans as both a prophet and a Messiah, though without endorsing the importance of Halakhic creativity. Though seclusion was important for him, it was of short duration and took place in a room at night, not outside of society. In other words, Abulafia only required seclusion for the moments to be dedicated to attaining peak experiences and otherwise remained socially active.

The approach to language and to the sacred text as embodied in the type of discourses found in Abulafia's writings versus those found in the Zoharic corpus is another criterion for easily and dramatically distinguishing between them. The pervasive use of gematrias when combined with philosophical allegorisation on an unprecedented scale either beforehand or afterwards in Kabbalah is marginal in the Zoharic literature, if present at all. All of them point to mental activities that dif-

that Abulafia's ecstatic experience is similar to that of the Zohar, itself a highly composite literary corpus, although she recognises that they make use of different terminology. This is a claim that is reminiscent of Wolfson, who knows that the experience in the "Zohar" was "genuine." See her "The Sixth Millennium," 67-68. For my approach, which pays maximum attention to the literary expressions of the mystical experiences rather than proclaiming their authenticity or alleged identity with other experiences, see Kabbalah: New Perspectives, 35-28, and Hellner-Eshed, A River Flows from Eden, 383, note 1. Earlier in Pedaya's works, she resorts to a different approach that allows for a much greater weight of the linguistic expressions in her analysis. See, for example, her Vision and Speech, 97. 94 See Idel, "On the Language of Ecstatic Experiences in Jewish Mysticism," 43-84.

95 Hellner-Eshed, A River Flows from Eden, 340-51.

96 Ravitzky, Maimonidean Essays, 40.

97 See Holzman, “State, Religion, and Spirituality, in the Thought of Rabbi Moses Narboni,” $191-211$. 
fer from the symbolisation that is based on discovering or unveiling correspondences with a higher, dynamic, and fluid level of the divine world and interacting with it.

No competent scholar would ever mistake a Zoharic passage for an Abulafian one, and vice versa; any claim to the contrary would, in my opinion, be a sign of deep ignorance in matters of Kabbalah that would discredit such a writer as a serious critical scholar. This is, to be sure, not just a matter of the Zoharic Aramaic versus the Tibbonian Hebrew, but also quite conflicting forms of imaginaire that operate in different ways. As Scholem duly formulated this difference: "The truth is that no two things could be more different than the outlook of the Zohar and that of Abulafia."98 Indeed, the Zoharic tone is much more descriptive, narrative, and essentially conjunctive-namely, it attempts to operate with the concept of Jewry as a national organic unit-while the Abulafian approach is more prescriptive and disjunctive, or exclusive, addressed as it is solely to the elite as individuals and despising the vulgus, Jewish or not, and even Rabbis, part of an anti-clerical attitude.

\section{6 "Phylacteries of the Holy One, blessed be He," and Phylacteries of Man}

Let me now discuss the special manner in which Abulafia approached a particular Rabbinic statement and compare it to that of the theosophical-theurgical Kabbalists. In a Talmudic tract, Rabbis portray God donning phylacteries and possessing a tallit. ${ }^{99}$ To be sure, the biblical text in God's phylacteries is different from that contained within the ordinary human ones: God was imagined as remembering not what He had done in illud tempus by rescuing the people of Israel from Egypt, but rather the uniqueness of the people of Israel and its relationship to Him. ${ }^{100}$ This discussion represents an important instance of reciprocal remembrance that occurs when the two different personalities, the human and the divine, don reminders on which the other is inscribed in so that they may perpetually remember each other. ${ }^{101}$ Various Jewish authors attempted to obliterate the anthropomorphic image-

98 Scholem, Major Trends in Jewish Mysticism, 130.

99 See BT, Berakhot, fol. 6a. For an analysis of the relevant text and its later reverberation of this issue, see Arthur Green, Keter: The Crown of God in Early Jewish Mysticism (Princeton: Princeton University Press, 1997), 53-56, 119-20, 139-40, 162. See also Raphael Loewe, “The Divine Garment and Shi'ur Qomah,” HTR 58 (1965): 153-60; Raphael Loewe, “Apologetic Motifs in the Targum to the Song of Songs," in Biblical Motifs: Origins and Transformations, ed. Alexander Altmann (Cambridge, MA: Harvard University Press, 1966): 159-96.

100 Berakhot, fol. 6a.

101 On the "envelope of reminders" in ancient Judaism and its later reverberations in Judaism, which includes the phylacteries, see Moshe Idel, "Memento Dei-Remarks on Remembering in Judaism,” in Il senso della memoria, Atti dei convegni Lincei (Rome: Accademia Nazionale dei Lincei, 2003): 143-94, especially 152-56, 172-74. 
ry in the Rabbinic passage by attributing it to a supreme angel or to an allegory of the entirety of reality; some even claim that it is not a reasonable story at all. ${ }^{102}$

However, Abulafia has a different approach, which is related to esotericism. Let me present a quote that reflects the manner of his approach to this case of Rabbinic anthropomorphism:

They are saying that "the Holy One, blessed be He, dons phylacteries" and they said "the phylacteries of the Holy Ones, blessed be He, what is written in them? 'And who is like your people Israel, one nation on the earth." ${ }^{103}$ Behold, they revealed that they were not phylacteries, since this [verse] is not written in our phylacteries, and if it was written there, they would indubitably be disqualified. And so also in all the places that you will find this in the hidden [layer] in the Written or Oral Torah, you will immediately find hints near to it that point to the truth of the issue and what the intention is in most places, or the author will rely on what is already widespread in tradition, such as "The Torah spoke in the language of humans"104 and "the Torah spoke in the language of fables," ${ }^{105}$ but the Torah did not speak except in order to popularise. And these are rousing everyone, and many like them in the two true Torahs, and it is not appropriate for a sage of our Torah to err concerning any of the vulgar, imaginary beliefs. ${ }^{106}$

Abulafia's approach is so antagonistic towards the content of the Rabbinic depiction of God donning phylacteries that he claims that this is quite impossible even according to the way the context should be understood. This means that by mentioning the biblical verse that the Rabbis attribute to the divine phylacteries, they are in fact invalidating them, since that biblical verse is not written in our phylacteries. This absurdity annuls the entire message regarding God's donning of phylacteries.

It may be that in addition to the problem of anthropomorphism, Abulafia also had a problem with the collective image of the people of Israel as a complete entity that should be remembered by God. In other words, for this Kabbalist, the Rabbis were writing for an intelligent audience that would understand from the context that the content of their narrative was, in fact, deriding anthropomorphism. This in-

102 See the comprehensive analysis of the history of this theme in Rabbinic and Kabbalistic sources, most of them predating Abulafia, in Adam Afterman, "The Phylacteries Knot: The History of a Jewish Icon” [Hebrew], in Myth, Ritual, and Mysticism: Studies in Honor of Professor Gruenwald, eds. Gideon Bohak, Ron Margolin, and Ishay Rosen-Zvi (Tel Aviv: Tel Aviv University Press, 2014): 441-80, and the important source discussed in Scholem, Origins of the Kabbalah, 212-14.

1032 Samuel 7:23.

104 Tosefta, BT, Baba' Meși 'a', fol. 31b. This dictum is used quite often in Abulafia's writings.

105 Sifri, Devarim, 25.

106 See Hayyei ha-Nefeš, 94-95:

אמרם שהקב"ה מניח תפילין, אמרו תפילין של הקב"ה מה כתיב בהן "ומי כעמך ישראל גוי אחד בארץ" (שמואל ב' ז:כג).

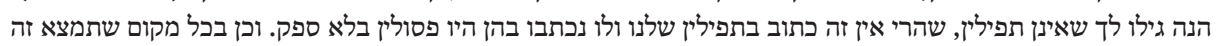

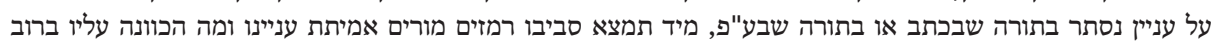

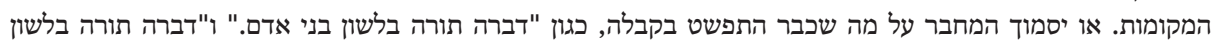

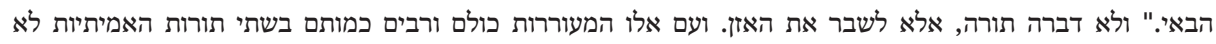

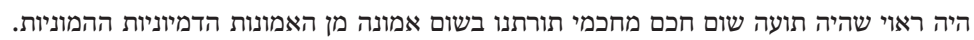
On Oral Torah in medieval Jewish thought, see Dov Schwartz, "Some Brief Comments on the Oral Law and Its Transmision in Jewish Thought” [Hebrew], in Study and Knowledge in Jewish Thought, 2:79-94. 
terpretation amounts to reading the Rabbinic passage in a Maimonidean-Straussian manner: the Rabbis are conceived as premeditatedly contradicting themselves so that only the intelligent reader could discern their real intention. Interestingly enough, in order to reject the validity of the above passage, Abulafia turns nomian and argues from the point of view of the Jewish law being against the Rabbinic micro-myth.

Let me compare Abulafia's attitude to the micro-myth to that of other Kabbalists. The famous late thirteenth-century Catalan Kabbalist Rabbi Bahya ben Asher wrote about the creation of the world following a Platonic approach that sees the archetype or prototype for all that was created below in the supernal world of forms. However, in addition to the structural correspondences between the Temple on earth and the supernal world, envisioned as a supernal Temple, the Kabbalist also assumes the possibility of the actual presence of the higher within the lower, a presence that creates a union between the two worlds. ${ }^{107}$ In this context, a description of the uniqueness of the people of Israel is offered:

"This is the great degree of Israel; they have a great adherence [devequt gadol] to the Holy One, blessed be He. This is the reason why it is written: "And you will be a special treasure unto Me." 108 The word "special treasure"109 points to the very thing within which there is a hidden power, as the "special treasure" is predicated on the power of grasses and pearls, within which there is a hidden power. And out of the strength of adherence [rov ha-devequt] [of Israel], God unifies and praises them as one nation. This is the reason why it is written in the phylacteries of God: ${ }^{110}$ "Who is like the people of Israel, a singular111 nation on earth"? unify Him and praise Him saying: ${ }^{113}$ "Hear, Israel: The Lord, our God, the Lord is one," etc. I too shall make you one unit in the world." 114

The importance of unity below, which is related to particularist chosenness, for achieving a state of union with God is obvious in this passage, as well as in the lines that follow it. Only by the Jewish nation being or becoming a monos is it possible to ad-

107 Cf. Rabbi Bahyya ben Asher, Kad ha-Qemah, Lulav, in Kitvei Rabbenu Bahya, ed. Chaim D. Chavel (Jerusalem: Mossad ha-Rav Kook, 1970), 234. See also Afterman, Devequt: Mystical Intimacy, 89-92, who pointed out to the source in Rabbi Judah ha-Levi. For Abulafia's account of the ascent to that Temple, see Idel, Ascensions on High, 173-77.

108 Exodus 19:5.

109 Segullah. In fact, Rabbi Bahya refers to a concept that is not biblical, but quite medieval; it deals with special qualities inherent in a few objects that cannot be described by means of regular physics.

110 BT, Berakhot, fol. 6 a.

111 Ehad, "one."

1121 Chronicles 17:21.

113 Deuteronomy 16:4.

114 Kad ha-Qemah, 234:

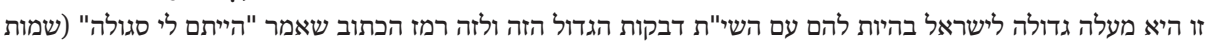

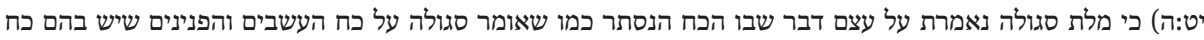

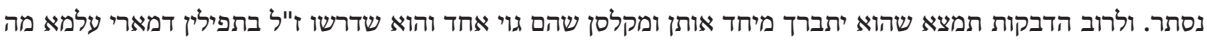
כתיב בהו "מי כעמך ישראל גוי אחד בארץ. כשם שהם מקלסים אותו ית' ואומרים שמות שמע ישראל ה' אלהינו ה' אחד וגו' אף 
here to the divine Monad. The fact that the unity of God is mentioned in the human phylacteries just as the unity of the people of Israel is mentioned in the divine phylacteries allows a reading that suggests that by remembering the one, it becomes one with the other.

I wonder whether the segullah is not only Israel as a nation, given what they say about God, but also the phylacteries, whose hidden treasures no one can see from the outside-that is, the formula of the divine unity. In any case, it is clear that the affinity between the two types of what I propose to call reminders (the human and the divine phylacteries) represent a union between Israel and God, who are reminded of each other through the texts found in their respective phylacteries. This is an interactive vision, and it refers to a reciprocal relationship between God and His chosen nation.

According to another of Abulafia's texts-which has several parallels in Kabbalah, ${ }^{115}$ one of which may serve as Rabbi Bahya's source-the divinity is portrayed as dwelling in someone who dons the phylacteries, a view that is consonant with the use of the term devequt in the above passage. ${ }^{116}$ Bahya follows the gist of the Rabbinic passage not only with his non-denial of the meaning of the mythical picture, but also by maintaining its national valence. This is also the case in the Zohar, which represents a strongly mythologising tendency that is part of a particularist approach. ${ }^{117}$ This means that the theosophical-theurgical Kabbalists celebrated the details of the Rabbinic micro-myth while Abulafia conceives what he considers its exoteric form as absurd, though in this case, he does not attempt to offer even an allegorical interpretation. Even a Maimonidean thinker was closer to the Rabbinic approach, as we may see in one of the writings of Rabbi Levi ben Abraham, with his emphasis on God's special relationship to the Jewish nation. ${ }^{118}$

Once again, Abulafia's approach differs not only from that of the theosophical Kabbalists, who were quite fond of the Rabbinic micro-myths and in some cases elaborated them into broader myths: he is also more radical than the Maimonideans. To a certain extent, this approach can be seen as complementary to the critique of the Rabbinic myth of the serpentine pollution that we discussed in chapter 9 above: the concrete language of the narratives that is so characteristic of the Rabbis is regarded as meaningless in favour of the more allegorical and naturalist understanding that Abulafia offers. They are also seen as self-contradictory and as requiring esoteric interpretation.

115 See, especially, Zohar 3, fols. 262b-263a.

116 See Bahya's Commentary on the Pentateuch, on Exodus 13:16, ed. Chavel, 104-5, and compare also to 268 in the same work.

117 3, fol. 175b. In general, see Oded Israeli, The Interpretation of Secrets and the Secret of Interpretation: Midrashic and Hermeneutic Strategies in Sabba' de-Mišpațim of the Zohar [Hebrew] (Los Angeles: Cherub Press, 2005).

118 See Liwyat Hen: The Work of the Chariot, ed. Kreisel, 187-88, in a context where the author explicitly refers to Kabbalists, and see also 287 in the same work. 
Let me turn to a closely related issue. According to another statement in the same Talmudic treatise, God showed Moses the knot of the phylacteries as part of an interpretation of the biblical assumption that He had shown His back to Moses. ${ }^{119}$ This micro-myth was perhaps part of a broader myth that also included the micro-myth of the divine phylacteries. Naturally, this image was reinterpreted in a variety of ways; Jewish philosophers interpreted the knot as an allegory for the concatenation of reality from the divinity and thus as a manner of knowing God. ${ }^{120}$

Abulafia also rejects the anthropomorphic micro-myth ${ }^{121}$ as he prefers a more unitive understanding of the event, since it originally tells us about a particular revelation to Moses. In the vein of his theory that Ha-QeŠeR means "the knot," while HeTeR means "unknotting"-both Hebrew terms amounting to $605^{122}$-the Rabbinic statement is conceived as an allegory for the soul's adherence to the supernal world after the knot, its connection to the material or the corporeal world, becomes unfettered. ${ }^{123}$

Elsewhere, he adopts a more ontological view that interprets the knot of the head phylactery as referring to the Account of the Chariot and the knot of the hand phylactery as referring to the Account of Creation. ${ }^{124}$ Again, Abulafia loads the exoteric passage with an esoteric meaning as part of what I call his arcanisation of Jewish texts. This is also the case in another of his treatments of the phylacteries:

[T] he secret that they testify to you the four witnesses ${ }^{125}$ that are on your head and they arouse you [...]. Know your head from your heart and also know your heart from your head. And this is the reason why your phylacteries were in two places on the body, on the head and on the weakened hand, which corresponds to the heart, and they are indubitably like amulets. And you already know what those who don the phylacteries say: ${ }^{126}$ "[the letters of] Adonai are upon them, [and] they will live"127 "and [the letters of] YHWH are on their head;" "128 afterwards, he said" "and their king passed before them." ${ }^{130}$

119 BT, Berakhot, fol. 7a.

120 See Afterman, "The Phylacteries Knot," 457-60, and Warren Zev Harvey's important analyses in his "Maimonides's Critical Epistemology and Guide 2:24," Aleph 8 (2008): 216-19.

121 Sefer ha-Melammed, 19-20.

122 See Idel, The Mystical Experience, 134-37.

123 Oșar 'Eden Ganuz, 2:9, 284, corrected according to the Ms.:

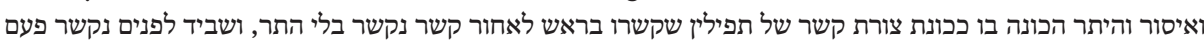

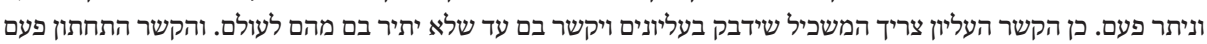
ידבק בו לפי צרכו אליו ופעם יותר ממנו לפי מעלת עצמו בערד אליו.

124 Sitrei Torah, 69. See also Oșar 'Eden Ganuz, 2:9, 277.

125 The four biblical pericopes found within the phylacteries of the head.

126 I have not found a Rabbinic source for Abulafia's claim.

127 Isaiah 38:16.

128 Micah 2:13.

129 Micah 2:13.

130 Oșar 'Eden Ganuz, 1:3, 127: 
Two phrases should draw the attention of the careful reader of this passage: the comparison of the phylacteries to amulets and the phrase "those who don phylacteries." The first phrase should be understood as part of Abulafia's more comprehensive rejection of all magic including amulets (qamei in), again following Maimonides. ${ }^{131}$ Especially telling is the term "indubitably" within this framework. It is a clearly negative comparison. This seems to me to also be the point of the second phrase, "those who don phylacteries" (menihei ha-tefillin), which conveys some form of implicit distance between himself and these traditional performances.

Who exactly these individuals are, literary sources or living Jews, is not clear, though the similarity to the views of Rabbi Bahya, written some few years after Abulafia's death, is quite interesting. His explanation is that the two parts of the body that are pertinent for understanding the donning of the phylacteries, the head and the heart, point to cognitive processes related to the brain and the heart. These two organs are understood to be related to the phylacteries in Rabbinic literature. This is also the case in another of Abulafia's discussions concerning the phylacteries, where we also find an interesting gematria:

And the secret of tefillin, four, hints to four pericopes which are ten, [namely] $\mathrm{ABCD},{ }^{132}$ and they come to stand against the evil inclination, born out of four luminaries ${ }^{133}[. .$.$] and the secret of the$ brain and the heart, Elohim, and within them the "light of Shadday" is emanating a "light of the sense," which is hot and humid in the blood. ${ }^{134}$

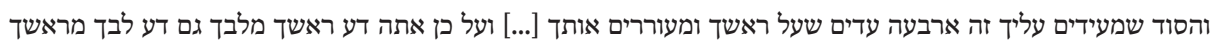

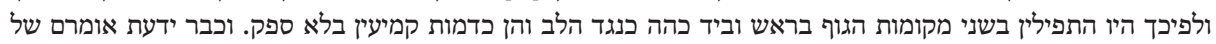

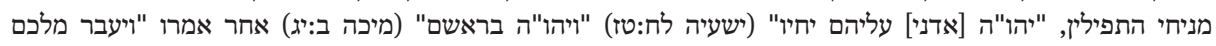

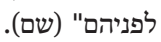

See also Meir bar Ilan, "So Shall They Put My Name upon the People of Israel (Num 6:27)" [Hebrew], HUCA 60 (1990): 19-31.

131 See Idel, “Abraham Abulafia: Between Magic of Names and Kabbalah of Names," 82-83; on Maimonides, see Ravitzky, Maimonidean Essays, 181-204.

132 In Hebrew 1+2+3+4=10. See also "We-Zot li-Yehudah," 20, and Wolfson, Abraham Abulafia, 149, note 153. This is an example of understanding an aspect of Jewish ritual (in this case, the four portions in the phylacteries) by means of resorting to its numerical structure and then to the Pythagorean theory of Tetraktys. This is described as including "hints," or, in other words, including some form of secrets.

133 It is not clear who these luminaries are; however, we may discern some form of cosmic approach based on non-theurgical types of correspondences.

134 Hayyei ha-Nefeš, 134, amended according to Ms. Munich, 408, fols. 87b-88a, and Ms. New York, JTS 1813, fol. 27ab:

וסוד התפלי"ן, ארבעה רמזים בארבע הפרשיות שהם י' אבג"ד. ובאו לעמוד כנגד יצ"ר הר"ע נולדו מארבע המאורים [...]

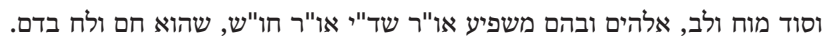

The New York JTS manuscript is a separate treatise that draws on material from Hayyei ha-Nefeš but is not identical to it, though it perhaps preserves a better version of the text. The same gematria, together with the Pythagorean Tetraktys, is found in a different version, Ms. New York, JTS 1813, fol. 27b. It is possible that Abulafia is referred to on fol. $27 \mathrm{~b}$ as the person who informed the anonymous Kabbalist about the gematrias. I hope to return to the Kabbalistic material found in this manuscript elsewhere. 
This short and compact passage is based on four series of gematrias. The first one, the Pythagorean, is decoded in the footnote. The second one is of special importance: ha-Tefillin $=$ yeșer $h a-r a^{c}=575$. The phylacteries are not conceived as identical to the evil inclination, as the gematria may be interpreted, but as standing against the evil inclination, reminiscent of the amuletic perception seen in the passage quoted above. However, the evil inclination is now considered to be an inner power, which means that the phylacteries are part of a struggle with the inner human inclination. This interpretation is corroborated by another important gematria found in the quoted text: moah wa-lev $=86=$ Elohim = ham we-lah. This means that the human body, especially the brain and the heart, is the recipient of the "light of Šaddai" (or Šaddai) or the "light of the sense" (or ḥuš), both amounting to 521.

Why are these issues considered to be secrets? It seems that the answer is quite simple: because the commandment of the phylactery is understood as referring to an inner process that is similar to what is found in many other cases in Abulafia, such as the secret of the reception of the Torah discussed above. ${ }^{135}$ Abulafia interiorised the apotropaic function of the ancient ritual and this is also the case in the manner in which he portrayed the Sinaitic revelation as restraining the sexual impulse. ${ }^{136} \mathrm{How}$ ever, this restraint should be understood as facilitating noetic actions rather than apotropaic ones.

Let me turn now to Abulafia's student Rabbi Nathan, the author of Ša'arei Ședeq, who promises that "if you will cleave to God, and link yourself to His power, your power will rule over the tefillin, which amounts in gematria to Yeșer ha-ra."137 Does such a text mean that there was an antinomian approach regarding the tefillin? I believe not. This gematria is simply part of an interpretive game that can change direction just as a positive approach to the same topic may do using another gematria. In more technical terms, I assume that as in many cases in ecstatic Kabbalah, the evil inclination refers to the imaginative faculty that is contrasted with the "good" inclination, the intellect. ${ }^{138}$ Flexible interpretations of words, even when associated with the commandments in Abulafia and his followers, do not automatically add to or detract from their behaviour. Did the Kabbalist who created the gematria for the evil instinct think that he was indeed donning the evil inclination when putting on tefillin? By untying one's soul or intellect from corporeality, one binds it to the intellectual world. ${ }^{139}$ This is a fine example of what I called a type of spiritual allegorisation.

135 See chapter 9 above.

136 See chapter 9 note 99 above.

137 See Rabbi Nathan, Ša'arei Ședeq, 465 and 476, to be quoted below on p. 288. For other analyses of tefillin in ecstatic Kabbalah, see Wolfson, Abraham Abulafia, 149-50, note 153.

138 See examples quoted in Idel, Language, Torah, and Hermeneutics, 44-45; Idel, The Mystical Experience, 96-97, 102-3; and Ša'arei Ședeq. Cf. Le Porte della Giustizia, 462-63.

139 Le Porte della Giustizia, 464-65. 
This theory about the tefillin recurs in Ša'arei Sedeq in a variety of forms, but I refer the reader to my detailed discussion of this issue elsewhere. ${ }^{140}$ Crucial for this book is the Neo-Platonic assumption that "nature" keeps the spiritual power within its dominion and that "divestment" means "escape from nature." ${ }^{141}$ In this book, the divestment is only once attributed to the intellect, which is depicted as becoming universal after separating itself from matter. ${ }^{142}$ Especially interesting is the mention of the divestment in quite an anomian context: "When she ${ }^{143}$ enters and is immersed in its innermost [aspect] and divests herself of the knot of the tefillin, which is the evil instinct according to the gematria, and binds $i^{144}[. .$.$] and the secret$ that you should receive from it is 'because ${ }^{145}$ the name is within it." 146 The divestment of corporeality or imagination, viewed as the evil instinct, is a matter of interiorisation. Thus, it is a nomian approach that informs the description of the very high perception of God according to Rabbinic sources, envisioning Him as performing a common Jewish commandment.

Abulafia recommends using the phylacteries as part of the preparations for performing one of his techniques that is to be carried out at midnight. ${ }^{147}$ Donning phylacteries during the night was certainly not a nomian performance, according to Rabbinic instructions, though it is not a sharp digression from the norm. In two instances that are parallel to the other two, phylacteries are not mentioned at all. ${ }^{148}$ I suspect, to put it mildly, that no phylacteries were used in the Friday night experience reported by Rabbi Nathan; at the very least, they are not mentioned. ${ }^{149}$ This means that they were indeed not considered to be strictly necessary for the technique.

Interestingly enough, in the early sixteenth century, Rabbi Judah Alboțini's ver-

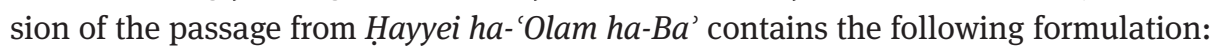

140 See Idel, The Mystical Experience, 134-37. The matter of the "fettering" and putting on of the spiritual form also appears in the Byzantine Kabbalistic book Sefer ha-Qanah (Koretz: 1784), fol. 106d: "And the intention is that Enoch divested the bodily element and put on the spiritual element and was fettered by a spiritual knot."

141 Le Porte della Giustizia, 467, 475. Compare also to 464-65.

142 Le Porte della Giustizia, 468-69. Compare also to Rabbi Judah Alboțini, Sullam ha-'Aliyyah, ed. Joseph E. E. Porush (Jerusalem: 1989), 71.

143 The subject matter is not clear. It is the letter Yod, but my assumption is that it is also the soul, as both are, grammatically speaking, feminine.

144 To the four biblical portions written in the phylacteries.

145 Exodus 23:21.

146 Le Porte della Giustizia, 476:

וכשהיא נכנסת ושוקעת לפנימיותה ומתפשטת מקשר התפלין אשר הוא יצר הרע בגימטרי' וקושרתו [...] והסוד קבל מזה

כי שמי בקרבו.

147 This is the case in Hayyei ha-'Olam ha-Ba' and in Or ha-Śekhel. See Idel, The Mystical Experience, 38-39, 120.

148 Sefer ha-Hešeq, 16, translated in Idel, The Mystical Experience, 38; see also Oșar 'Eden Ganuz, 3:10, 365.

149 Le Porte della Giustizia, 479. 
If you can, ${ }^{150}$ wrap yourself in a tallit and don your tefillin on your head and your arm, so that you may be fearful and in awe of the Šekhinah, which is with you at that time. And cleanse yourself and your garments, and if you can, have them all be white, ${ }^{151}$ for all this greatly assists the intention of fear and love. ${ }^{152}$

Thus, phylacteries and the ritualistic shawl, the tallit, are conceived as being helpful for inducing a certain state of mind rather than for keeping certain commandments. They do not ensure the presence of the Šekhinah, but rather the appropriate attitude towards her presence, which is produced by the recitation of divine names or combinations of letters. In his Or ha-Śekhel, Abulafia also recommends them as an option: "And sit wrapped in pure clean white garments or new garments over all your garments or have your tallit and your head adorned with tefillin."153

The "or" here parallels the "if you can" in the Hayyei ha-'Olam ha-Ba' version and demonstrates that for Abulafia, white clothes are more essential than the traditional ritual objects. In this case, only the phylactery of the head is mentioned, not that of the hand! Interestingly enough, in a Vatican manuscript of Or ha-Śekhel, there is a painting illustrating Abulafia's technique where the figure dons the head phylacteries: his left hand, quite visible in the picture, has no sign of phylacteries. ${ }^{154}$ From the dark background that surrounds the figure, it is more than plausible that night is implied as the moment for the recitation of the combinations of letters. Not quite a hypernomian approach, to be sure.

In the third case, when describing the preparations for recitation, Abulafia ignores the issue of wearing phylacteries altogether. ${ }^{155}$ In a passage from an unidentified text that is most plausibly part of ecstatic Kabbalah and preserved by Rabbi Hayyim Vițal, we read as follows: "Isolate yourself in a house and close your eyes, and if you can wrap yourself in a tallit and tefillin, it would be better." 156 The explicitly optional use of external accoutrements from the liturgical ritual helps to account for the absence of țallit and tefillin in Rabbi Nathan's version in Ša'arei Ședeq. In any case, both the absence of the recommendation to wear the tefillin when reciting the divine name in solitude and the above gematria, to say nothing of the optional formula-

150 Here and again below the Hebrew phrase is im tukhal.

151 See Ecclesiastes 9:8. The sources for white clothes are numerous and include many magical texts. The closest, however, is Rabbi Eleazar of Worms's Sefer ha-Šem. See Wolfson, Through a Speculum That Shines, 237, note 195, and Rabbi Judah ben Nissim ibn Malka, Kitāb Uns wa-Tafsīr, ed. Yehuda A. Vajda (Ramat-Gan: Bar-Ilan University Press, 1974), 53.

152 Alboțini's Sullam ha- 'Aliyyah, 73. Compare to Hayyei ha-'Olam ha-Ba', Ms. Oxford, Bodleian 1582, fol. 51b.

153 Or ha-Śekhel, Ms. Vatican, 233, fol. 109a, 105. See Wolfson, Abraham Abulafia, 223-24.

154 See Ms. Vatican, 597, fol. 113a.

155 See the passage in Sefer ha-Hešeq mentioned in chapter 26 note 148 below. Compare to Wolfson, Abraham Abulafia, 209. Wolfson contends that the donning of the țallit and tefillin are "essential" for the recitation because the latter are no more than "an extension of traditional prayer." See also Appendix E note 219 below.

156 Ša'arei Qedušah (Jerusalem: 1973), 7. 
tions, are far from suggesting that this Kabbalist believed that ecstatic Kabbalah was closer to the ritual core of Judaism than philosophy, as a hypernomian might think. ${ }^{157}$

Interestingly enough, the only instance, to my knowledge, where the donning of the tallit and tefillin is not presented as optional is in the version copied from Or haSekhel by the early sixteenth-century Kabbalist Rabbi Judah Alboțini, who was active in Jerusalem. ${ }^{158}$ Albotini was a Halakhic figure, unlike Abulafia and Rabbi Nathan, a fact that may account for the change he made in Abulafia's advice. Reading the anomian framework through the lens of a nomian figure like Albotini does not, however, make the anomian hypernomian.

Clearly, ecstatic Kabbalah's approach to mystical techniques can be categorised as anomian rather than hypernomian in that-with due respect to Wolfson's claims ${ }^{159}$ -neither Abulafia nor Rabbi Nathan attempted to expand the range of ritual, but they rather strove to validate their own (anomian) techniques that were derived from Sefer Yeșirah, itself an anomian text, and from the combinatory techniques found among the Hasidei Ashkenaz. These linguistic methods are a skeleton onto which Abulafia incorporates optional technical elements that are designed to inspire awe and a sense of mysteriousness in the atmosphere that surrounds the performance of their combinatory techniques.

The auxiliary status of the phylacteries becomes especially clear when we realise that there is no synchronicity between the ritual acts that are regularly performed in the morning and the mystical techniques that form the core of the ecstatic method. The liturgical artefacts constitute ornaments, as Abulafia himself states, and are not accompanied by any special consideration related to their religious meaning.

In order to better understand their role in Abulafia's technique and its psychoritual background, his advice needs to be compared to a magical formula attributed to the thirteenth-century Rabbi Elijah of London: "When you wish [...] to formulate your question, turn your heart away from all other involvements, and unify your intention and your thoughts to enter the Pardes. ${ }^{160}$ Sit alone in awe, wrapped in tallit

157 See Wolfson, Abraham Abulafia, 227, on the basis of Ša'arei Ședeq, Le Porte della Giustizia, 477. The hypernomian implication this scholar finds there is unwarranted by the material. For an example of hypernomianism, see the assumption of a somewhat later Kabbalist, the author of Tiqqunei Zohar, who speaks about the Šekhinah donning the phylacteries. Cf. Roi, "The Myth of the Šekhina in Tiqqunei ha-Zohar," 280-82. See also chapter 16 note 118 above.

158 See Sullam ha-'Aliyyah, ed. Porush, 69.

159 See Wolfson, Abraham Abulafia, 209-10. For an earlier use of the term "hypernomism" in the context of Kabbalistic material, see Talya Fishman, “A Kabbalistic Perspective on Gender-Specific Commandments: On the Interplay of Symbols and Society,” AJS Review 17 (1992): 199-245. Unlike my view of Abulafia as a universalist versus Wolfson's view of him as a particularist, which I based on texts that have been ignored, in the case of the nature of the technique, the difference between us is a matter of differing interpretations of, roughly speaking, the same texts.

160 Namely, the orchard described in many Jewish texts as a supernal level of reality that can be experienced. 
and with tefillin on your head, and begin [to recite the] 'Mikhtam for David,'161 the entire psalm [...] and read them with their melodies." 162 This passage is certainly influenced by Kabbalistic thought, but I would not date it to the thirteenth century, even though it is attributed to Rabbi Elijah of London. ${ }^{163}$ Nevertheless, its similarities to Abulafia's technique are fascinating, especially the mention of melodies. It can serve as a foil for what we learn from the ecstatic Kabbalist. ${ }^{164}$ First and foremost, the recited text is a nomian one, a Psalm, and not a divine name. Moreover, the tallit and tefillin are not means to induce awe, as this is a state of mind already mentioned beforehand. There is nothing optional here: this technique is formulated in a non-conditional manner.

In another formula from the same codex, which is one of the most important Hebrew magical manuscripts, we find:

\begin{abstract}
You may picture the Ineffable Name like the white flame of the candle, in absolute whiteness, and [like] the light when looking at the candle, and even when there is no candle, remember the flame, and there you may see and look at the light, [which stems] from the pure white light. And you must always imagine that you are a soul without a body, ${ }^{165}$ and the soul is the light, and you are always within the flames, in the pure clouds. ${ }^{166}$ And strive to be pure and complete [or perfect], and if it is daytime, wear șisit and tefillin and the ring upon your finger, and at night as well, [wear] the ring upon your finger. And be accustomed to cleanliness in that house where you stand in the sanctuary of God, ${ }^{167}$ within His precious, holy, and pure names. ${ }^{168}$
\end{abstract}

Here, the anonymous author is well-aware that one does not wear phylacteries at night. This ascension on high has both a mystical and a magical component, as the reference to a ring shows. However, unlike the attitude in the two later texts, Abulafia's is not sacramental. The details he recommends are intended to change one's psychological atmosphere before beginning the recitations of the combinations of letters.

161 Ps. 16. This psalm had a profound impact on Jewish mysticism, especially verse 8.

162 Ms. Sassoon 290, 381.

163 On this figure, see Amos Goldreich, Automatic Writing in Zoharic Literature, especially the index entry for Eliyahu Menahem ben Moshe mi-London.

164 On music as part of Abulafia's technique, see Idel, The Mystical Experience, 53-71.

165 See Vital, "The Fourth Part of Ša'arei Qedušah,” in Ketavim Hadašim me-Rabbenu Hayyim Vițal, ed. Nathanel Safrin (Jerusalem: Ahavat Shalom, 1988), 10; Lawrence Fine, "Recitation of Mishnah as a Vehicle for Mystical Inspiration: A Contemplative Technique Taught by Hayyim Vital," REJ 141 (1982): 197.

166 See the Abulafian description of the continuum of God as intellect, the separate intellects, and the human intellect as lights within a candle, quoted in Idel, The Mystical Experience, 130-31.

167 On the metaphorical resort to terms related to sanctuary, see also chapter 25 above.

168 Ms. Sassoon 290, 648. This manuscript was mainly copied before the peak of Safedian Kabbalah, although its later parts reflect the impact of Safedian theories. 


\section{Some Methodological Remarks}

Let me compare Abulafia's thought to the approach of the Maimonideans, as well as to the approach(es) of most of the other Kabbalists. In the case of the former, his thought diverges in his strong naturalist approach to language, which is conceived as a natural phenomenon related to speech. It is a specifically human feature: humans are speaking and intelligent beings. Abulafia's emphasis on the superiority of the divine names as being conducive to a form of sublime intellection is hardly approximated by the Maimonideans, whose approach to language was essentially informed by its conventionality. Moreover, unlike the more scholastic approach of the Maimonideans, Abulafia developed a much more spiritualist approach that concerned his life and those of his students and not merely theoretical discussions about prophecy or the allegorical exegesis of ancient texts. Finally, his strong eschatological propensities, either individual or collective, are hardly paralleled by any of the followers of the Great Eagle.

Abulafia's pointed critique of theosophical Kabbalah is unparalleled by any other polemic within the Kabbalistic camp in the entire thirteenth century; it is one of the sharpest assaults on this type of Kabbalah ever given. In my opinion, it is not just a matter of an attitude adopted in a moment of intense controversy. On the contrary: his critique of those Kabbalists as being worse, theologically speaking, than Trinitarian Christians would have been counterproductive for someone who was attempting to find a way to mitigate the critique of ibn Adret, as is obvious from his epistle to the latter's colleague in Barcelona, Rabbi Judah Salmon. ${ }^{169}$ Moreover, also in other contexts, and not just polemical ones, Abulafia rejects theosophy. ${ }^{170}$

This is also the case with his attitude towards theurgy, as I discussed above. ${ }^{171}$ His explicit critique of symbolism as practised by the theosophical Kabbalists touches another major topic on the manner in which the Kabbalists in Spain elaborated their discourse. ${ }^{172}$ This topic also links to his special type of esotericism, most of which is closer to the philosophers and to Ashkenazi thought. In short, all of these critiques should be seen as part of the intellectual philosophical mould that informed Abulafia as a matter of principle, not just as a matter of historical conjecture.

Abulafia's acquaintance with the thought of the faläsifah is one of the reasons behind his approach, which caused a shift in the centre of the human ideal activity that was decidedly different from the theosophical Kabbalists. Following a Maimonidean, ultimately Greek, propensity, he shifted the emphasis from what I call the performing body that concerns the Rabbinic tradition and the integration of the perfor-

169 Ed. Jellinek, 19, quoted below in Appendix C.

170 See Oșar 'Eden Ganuz, 1:1, 40.

171 See chapter 17 note 154 above.

172 See the passage translated above from Imrei Šefer, 18. 
mance of both body and soul that concerns most of the Kabbalistic traditions ${ }^{173}$ to intellectual operations or, more rarely, to processes in the external reality. He considered them as secrets on the one hand and as sublime ideals to be attained on the other.

These differences and others separate Abulafia from the two main alternative camps to which he should be compared: the Maimonideans and the theosophicaltheurgical Kabbalists. He was a significant member of the former, but was acquainted with and critical of the latter, which is evident not just from his biography, but also from the content of his books, when understood as he would have liked them to be. Nevertheless, given his synthetic approach, he differed dramatically from both. At least in the case of the theosophical Kabbalists, the rejection was quite explicit and sharp, as we learn from ibn Adret's influential attitude and from the more elaborate attack by Rabbi Judah Hayyat made at the end of the fifteenth century. ${ }^{174}$

Thus, both conceptually and socially, Abulafia remained outside the Spanish Kabbalists' camp for two full centuries after his death. This reciprocal rejection is unparalleled in the case of any other Kabbalist from those centuries and it was only through the restructuring of the Spanish Kabbalah after the expulsion of the Jews from Spain that the enmity of the Spanish Kabbalists towards his sort of Kabbalah was mitigated. The modern scholarly attempts to reduce the gap between the two forms of Kabbalah ignore the importance both of the histories of Kabbalah and of its phenomenological variety, as Scholem and I have proposed by elaborating on Abulafia's own typology to a great extent. However, Abulafia's esotericism should be seen as part of a much broader phenomenon which included Jewish philosophy, Kabbalah, and Ashkenazi literature: what I call the profound arcanisation of Judaism. Though there were plenty of secrets in Qumran, Rabbinic, magical, and Hekhalot literatures, those secrets were nevertheless contained in only a few areas. However, from the twelfth century, an accelerated process of more comprehensive interpretations of Judaism as constituted by secret messages, and more rarely mysterious ones, took place, with the late thirteenth century as one of the peaks of this process that would develop for four further centuries.

Though much more a matter of rhetoric than of practice, the vector was definitely in the direction of a proliferation of secrets in general, including areas of secrecy that earlier had not been conceived as esoteric. The founder of ecstatic Kabbalah was active at the intersection of most of these types of esotericism and his approach, though profoundly influenced by philosophical esotericism, did not exclude the astral one

173 See Idel, “On the Performing Body,” 251-71, and Idel, “Nišmat Eloha: On the Divinity of the Soul in Nahmanides and His School." Let me point out the difference between the theosophical Kabbalists' assumption that the soul is divine, has descended here below, and is striving to return to the supernal source versus Abulafia's emphasis on the intellect that grows from its potential to actual status. Thus, even when the two types of Kabbalah discuss the same issue, such as devequt, the issue means quite different things in the different systems of thought.

174 See Idel, Kabbalah in Italy, 221. 
as advocated by Abraham ibn Ezra or the Ashkenazi one, and he mentions the theosophical-theurgical issues only rarely and rhetorically.

Moreover, unlike other medieval authors, Abulafia is one of the very few whose rhetoric includes the assumption that secrets may be inserted into the interpreted texts through a conscious process of secretive eisegesis that I call comprehensive arcanisation, which means that secrets were not only elicited from the interpreted texts, but also projected into them by means of a variety of exegetical methods that he described. ${ }^{175}$

By unveiling the dominantly political nature of those secrets whose importance Abulafia deemed worthwhile either to put into relief or to hide, we may have a more solid insight into the specific nature of his speculative axiology. Natural processes and natural linguistics, envisioned as conducive to sublime noetic processes, are the clues for understanding his esoteric axiology. This is the reason why it is difficult for me to understand why some scholars attempt to mitigate the central role the noetic processes played in his writings while blurring the phenomenological divergences between his writings and those of the theosophical Kabbalists whose conceptual worldviews were so different on this point.

It is Neo-Aristotelian philosophy that serves as the main source of the hermeneutical grid for reinterpreting the earlier layers of Judaism in a manner that gravitates around noetic processes. This means that Abulafia possesses a naturalistic understanding of religion that brings together the Neo-Aristotelian intellectual apparatus, non-linguistic in nature, with the cosmology and linguistics of Sefer Yeșirah, whose worldview he interprets in a strongly naturalistic manner. As Abulafia indicates, these two sources should be seen as coefficient but insufficient if separated from one another. ${ }^{176}$ It is here that the originality of Abulafia's writings can be discerned because unlike the other Kabbalists, he does not betray his earlier adherence to Maimonides, and unlike the Maimonideans, he does not remain imprisoned in a scholastic approach based on Arabic-Jewish Neo-Aristotelianism and its application to the religious texts by means of allegories and homonyms.

Abulafia's approach is a hybrid approach that brings together these disparate realms-linguistic speculations with intellectualistic ones through modifying each of them, especially the former-despite their significant conceptual dissonance. For example, he inserted linguistic elements into Maimonides's philosophical definition of prophecy on the one hand and loaded these elements-namely, the Hebrew letters and the divine names and their combinations-with an intellectual cargo on the other. ${ }^{177}$ This more philosophically oriented conceptualisation of the sources of Abulafia's thought is also true in the case of the extant lists of the books he claims to have studied; we are indeed able to definitively ascertain that he used them in his

175 This process is described in Idel, Absorbing Perfections.

176 Oșar 'Eden Ganuz, 1:1, 33. On Abulafia's preference of the phonetic over the graphic elements of language, see my Language, Torah, and Hermeneutics, 135, note 11.

177 See, for example, Sitrei Torah, 160, and Oșar 'Eden Ganuz, Ms. Oxford, Bodleian 1580, fol. 90a. 
writings. His claims are not just boasting, as is the case of Rabbi Hillel according to Joseph B. Sermoneta.

With this approach in mind, the more specific analyses of topics above allow for the understanding of Abulafia's worldview as presupposing a rather stable universe within whose framework it is possible for a man to achieve some form of sublime noetic experiences through resorting to techniques Abulafia articulated starting from $1280 .{ }^{178}$ This natural stability should be seen against the background of its author: an itinerant thinker, often in motion from one country to another, who believed that he was living in a time of dramatic transition and who interpreted the words of the texts as having been manipulated in a variety of ways so that through new combinations of letters, he could introduce a variety of meanings stemming from his own mind.

On the grounds of the materials adduced above, some of which have not yet been discussed in scholarship, it seems quite plausible that Abulafia was inclined to a more universalistic conception of man (within the constraints of his time and place) than most of his thirteenth-century contemporaries, with the possible exception of Rabbi Menahem ha-Me'iri. Even the Ancient Greek philosophers who contributed so much to the emergence of the universalist approach had their prejudices, as the use of the word "barbarian" shows.

Especially surprising are the recent depictions of Abulafia's thought as particularist and the assumption that he adopted theosophical views. ${ }^{179}$ These descriptions are missing an accurate understanding of the main point of his Kabbalistic enterprise: in some instances, he allegorises Kabbalistic symbolism, just as he allegorises biblical verses or Rabbinic legends. Without seeing a more comprehensive and complex picture based on the entire range of pertinent discussions, the scholar and the reader are lost in details that may not fit the more complex intention of the author or the general picture as it emerges from the specifics of its literary presentation. Therefore, they generate some analyses of details in a rather surprising manner.

It is particularly important to decode the specific types of discourse, replete with both allegories and gematrias that are hardly found in Kabbalistic literature before Abulafia and the circle related to him, as well as the content of his secrets. No doubt this is one of the most complex types of discourse, which necessitates much more than just decoding numerical equivalences: it also requires an attempt to understand the types of narratives he uses, either alone or together.

Through the unnecessary efforts to reduce the importance of the philosophical dimensions of Abulafia's thought that are too obvious in almost all of his studies on the topic along with an overemphasis on a few theosophical themes found in some of his writings-which, in my opinion, Abulafia often reinterpreted in a new,

178 See Appendix B below.

179 See the subtitle of Wolfson's book on Abraham Abulafia in which both theurgy and theosophy are mentioned. 
non-theosophical manner that was essentially a phenomenon of allegorising symbolism ${ }^{180}$-Elliot Wolfson has striven to soften the phenomenological gap between the two major forms of Kabbalah in the thirteenth century. ${ }^{181}$ In this context, let me note that he has also overemphasised the impact of Maimonides on the theosophical Kabbalists, again blurring the sharp divergences between the two forms of Kabbalah. ${ }^{182}$

There is no reason not to highlight the profound affinities between Abulafia's theories and various forms of philosophy, especially Maimonidean ones. Otherwise, the core of his message remains solely within the second narrative, as is indeed the case in some of Wolfson's particularist readings of this Kabbalist. This amounts to an exoteric understanding of a person whom I consider to be an esoteric Kabbalist. Abulafia has therefore been judged by scholars on the level he wanted to project for the unqualified readers, the vulgus, while the secrets that he wanted to hide have remained hidden in the recent scholarship on his thought. ${ }^{183}$ At the same time as he tries to uncover the phallocentric "secret" of Kabbalah, envisioning the divine perfection as a male androgyne and imagining that this disclosure of his well-kept secret transforms Abulafia into a heretic in the eyes of other scholars of Kabbalah, Wolfson ${ }^{184}$ reads Abulafia, who was banned and deemed heretical in his lifetime and also for many years afterwards, in quite a harmonistic manner, as a particularist Kabbalist like all the others.

The question that should therefore be asked at this stage of our discussion is: if Abulafia resorts to more traditional explanations of topics in many places in his writ-

180 I have prepared a separate study on this phenomenon.

181 For the assumption of a substantial bifurcation in the phenomenology of Kabbalah as pointed out by Abulafia himself, see my Kabbalah: New Perspectives; Idel, The Mystical Experience, 7-10; Idel, Language, Torah, and Hermeneutics, xii-xvii; Idel, "The Contribution of Abraham Abulafia's Kabbalah," 117-43; and Idel, "On the Meanings of the Term "Kabbalah," 40-52. I hope to return to this issue in a more expanded manner based on some texts that have not yet been taken into consideration in another study.

182 See, more recently, Wolfson, "Kenotic Overflow and Temporal Transcendence." This is also the case in the study by Lachter, "Kabbalah, Philosophy and the Jewish-Christian Debate," 1-58, who, in my opinion, overemphasises some themes as if Gikatilla's "immersion" in theosophical imagery is already present in his early writings. In this case, just as in Wolfson and Sagerman's approach, we may discern the same sort of effort to "theosophise" material that is not concerned with theosophy through assuming an esoteric theosophical level. In these cases, the scholars analyse only disparate themes of these materials rather than their profound structures, and then some form of implicit conclusion as to a hidden layer of thought is drawn. Though different from Abulafia's more naturalistic approach and his more sympathetic attitude to philosophy, Gikatilla's early worldview also differs dramatically from the Kabbalistic theosophy that he would so magnificently expose in his later Kabbalistic books. See Scholem, The Kabbalah of Sefer ha-Temunah, 108-10.

183 This, in my opinion, is also the case in Wolfson's discussion of the rationales of the commandments, where he distinguishes between esoteric and exoteric levels. See his Abraham Abulafia, 18697, and see, for the time being, my "On the Secrets of the Torah in Abraham Abulafia," 430-51. 184 See Elliot R. Wolfson, "Gender and Heresy in the Study of Kabbalah," Kabbalah 6 (2001): 231-62. 
ings, but in one or more cases offers secret views that contradict the former, are the former exoteric expressions a cover for the esoteric ones? This is a crucial issue that cannot be answered in general terms without a detailed analysis of the meaning of the various secrets themselves. However, on the grounds of Abulafia's resort to the phrase "Holy Language" in both the traditional sense and in its esoteric and naturalist sense, which differs so significantly from its exoteric understanding, as has been presented above, and of the secret of the divine choice, I am inclined to offer a positive answer.

This is also the case with the interpretation I have given of the parable of the pearl, as well as that of his reinterpretation of popular messianism as ultimately speaking about an individualistic kind of redemption. In some cases, though not all, the secrets that Abulafia conceives as important are highlighted with terms like "wondrous" and other similar adjectives. My assumption as to the importance of these secrets is not a subjective evaluation.

In other words, we should take Abulafia's indications as to what is important much more seriously than they were taken in the past. To put it another way: in my opinion, Abulafia was a Maimonidean not just in what he said or in his resort to Neo-Aristotelian nomenclature, but also in the manner in which he hid matters, both through the strategy of homonyms and, which seems to me to be even more important, in the nature of the matters he decided to hide themselves. Such Maimonidean esotericism, which is essentially political in nature, is even more surprising for a Kabbalist who claimed that the time of the end had arrived and that the secrets should be revealed; that is, he claimed that the stark distinction between the vulgar and the elite had been mitigated.

I would also like to point out the difference between Maimonides's economy of esotericism and Abulafia's. The Great Eagle assumed that his book, The Guide of the Perplexed, was a self-contained unit that served as the sole container of his secrets. They are spread and hidden within the contradictions and hints found in this single and very carefully written book. This does not mean that his two earlier major books are not mentioned or that they cannot help us to understand his secrets. However, these books were built on other strategies of hiding secrets to those adopted in the Guide, and secrets were not the author's primary intention for writing them.

In this book, I have culled passages from around three dozen of Abulafia's texts. From these passages, it is clear that Abulafia adopted a different strategy that necessitated not only considering the different wavelengths or registers for different audiences, as was also the case for Maimonides himself, but also developments in his own thought over the course of twenty years. Moreover, Abulafia wrote his numerous books under the impression (or in the confidence) that he was living and acting during a special moment in history, as well as that he was playing a unique, redemptive role, at least according to the historical narrative. It should be mentioned that Abulafia could not have imagined that his most avid reader would have possessed all of his writings, which were composed in different countries and for different audiences. Therefore, contradictions may not only be a matter of deliberate authorial decisions, 
as is explicitly the case with Maimonides's esotericism, but also of conceptual fluidity, which should be taken into consideration when dealing with his thematic approach.

What cannot be denied, however, is the fact that Abulafia repeatedly pointed to the existence of secrets, including extreme epithets that refer to his emphasis on the special importance of some of them in particular. He also provides expressions of heterodox ideas, sometimes in a clear manner, in his rebuttal of the Rabbinic theory of pollution and his rather convoluted treatments of the problems of the nature of the choosing of the Jewish people and the freedom of the divine will. Though these issues are different themes, they are all related to each other, and they are part of the profound structure of Abulafia's teachings. These are questions, tensions, and frictions that generated stark opposition through the introduction of naturalist themes into a particularist religion; the tensions found in Abulafia's texts were translated in the public arena through his banishment by ibn Adret.

In more general terms, the question is: to what extent were the contents of Abulafia's writings, which he would call Kabbalah, identical to his own esotericism? In my opinion, the answer is complex. At least in one case, Abulafia distinguishes between the Kabbalistic interpretation, seen as the plain sense, and the secret meaning of a certain commandment. ${ }^{185}$ Though he envisioned ecstatic Kabbalah as the path leading to what he conceived as being the highest experience, be it prophetic or messianic, this is not necessarily an esoteric issue, though the identification of the prophet or the Messiah with a certain specific person may indeed be part of eschatological esotericism. The highest experience, that of mystical union in itself, does not have to be related to esotericism, which, in my opinion, should be essentially understood in a political manner; namely, as being intended to hide the religious framework which frames the experience: the naturalist-inclined religion that is an important register, which includes the centrality of the noetic transformation, in strident opposition to the traditional forms of Jewish religion, with its emphasis on the centrality of the performance of rituals.

This conclusion can be formulated in more general categories: the religious framework (Abulafia's theology and cosmology) is essentially naturalistic, a fact that allows for the accomplishment of the highest experience through a mental process. The two intertwined aspects, the natural and the mental, belong to the third narrative. These two elements, both by their nature and by the sources that inspired Abulafia, are rather universalist. In my opinion, the anomian character of Abulafia's techniques assumes the possibility of attaining these experiences in a short time by resorting to linguistic repetitions and bodily acts that are not dependent on the Rabbinic rituals. These practices are reminiscent of Hindu, Hesychastic, and perhaps 
also Sufi techniques. ${ }^{186}$ The role of the divine will in preventing the achievement of prophecy is negligible in Abulafia's writings, thus allowing the performance of his techniques to be the main means of obtaining a prophetic experience, though it would ideally be preceded by some form of philosophical education.

In general, Wolfson's approach to Abulafia as a particularist and his more concrete readings of Abulafia's statements-taking as he does the national-historical narrative of the parable of the pearl as if it were the main message that Abulafia intended to convey-differs from my emphasis on the centrality of the metaphorical and allegorical aspects of his texts. My approach is much more inclined towards the universal dimension of his thought, which is either only succinctly mentioned or is carefully hidden in his works. This dimension informs the manner of reading his writings I have provided above.

Our approaches also differ insofar as the attitude towards commandments is concerned: my assumption is that Abulafia's techniques are anomian, and subsequently less dependent on Rabbinic rituals, if at all, while Wolfson assumes that they are "hypernomian" and thus that they strengthen these rituals. These substantial differences have had an impact on our general understandings of Kabbalah: I assume a greater polarisation of camps or schools and see a much less homogeneous view of the field, while Wolfson blurs some of what I see as the most vital differences between them, offering a more theosophical understanding of all Kabbalistic phenomena. Indeed, these two readings still deserve additional special, critical, and detailed studies that discuss the appropriateness of these two diverging scholarly analyses of and approaches to these specific texts.

My call for a comprehensive understanding and attentive reading of details and discerning contradictions, based on weighing the nature and continuing impact of Abulafia's philosophical sources, is indeed one of the reasons why I decided to provide most of the original Hebrew texts in the footnotes of this book: in this way, a more informed type of argumentation can be undertaken by scholars. The fact that some of the texts dealt with here are only available in manuscript form has also encouraged me to provide the Hebrew originals. From perusing scholarship in this specific field, scholars do not turn to the manuscripts often enough in order to ascertain the accuracy of a translation or interpretation, and seldom search for yet unidentified texts in manuscripts belonging to ecstatic Kabbalah. Even supposing the mere existence of such texts barely surfaces in recent scholarship.

Let me point out that since my description of Abulafia's literary corpus in my $\mathrm{PhD}$ dissertation submitted in 1976, scholars writing entire books have not found

186 See my The Mystical Experience, 13-52, and Studies in Ecstatic Kabbalah. Let me point out that the Sufi impact on Abulafia has been exaggerated in recent years on the basis of very scant grounds; I hope to return to this issue elsewhere. See Pedaya, Vision and Speech, 195-98; Hames, "A Seal within a Seal," 153-72; Hames, Like Angels on Jacob's Ladder, 34-35; Idel "Definitions of Prophecy: Maimonides and Abulafia," 33, note 21; Idel, "Sefer Yetzirah and Its Commentaries," 492, note 59; and chapter 24 note 20 above. 
even a single previously unknown page belonging to this Kabbalist, even in the case of an industrious scholar like Elliot Wolfson, who has published a great deal about Abulafia and regularly reads manuscripts. This is a rather surprising situation, given the fact that it is still possible to find new materials belonging to Abulafia and his school in manuscript (and even in print) that were unknown to me at that point in time. As I have done in several of my earlier studies, in my discussions above I have brought forth manuscript materials from texts that I did not deal with in my dissertation, ${ }^{187}$ and I also hope to do so in additional studies concerning several unidentified texts in the near future.

Unfortunately, recent studies of Abulafia rely-with many omissions and with what I consider to be bibliographical mistakes-on only a small portion of the material I already outlined in 1976 and in some studies written afterwards. The authors of these studies only seem to use the recent printed editions of his works, which are not always reliable, and neglect new material that is still extant only in manuscript form. Although access to hundreds of unknown manuscripts is more facilitated than it has ever been in Jewish history, the study of the range of material found in these manuscripts has been surprisingly limited, even more than in the very beginning of the study of Kabbalah by the likes of Adolph Jellinek and Gershom Scholem, who did not enjoy the technological possibilities available today. However, what seems to be more problematic is not just the sometimes lazy resort to printed works (often without any reference to my 1976 identifications of manuscript texts and sources belonging to Abulafia): rather, some scholars' selective reading of his texts is caused by their selective manner of treating the pertinent material and above all their ignoring of the content of the esoteric dimensions of his writings.

The selective manner in which the content of these printed books has been presented is often informed by a more comprehensive agenda, as we have seen above in the case of the treatment of the pollution myth.

The impression these scholars give is that they are less committed to a serious acquaintance with the details of the complex field in which Abulafia wrote than what would be expected. The manner in which Abulafia's treatment of the Rabbinic statement on the primordial pollution and the cathartic Sinaitic experience has been discussed is based solely on one discussion among many others, and Pedaya's treatment of Abulafia's interpretations of the phrase "end of time" are examples of a fragmentary and sometimes impressionistic presentation of the rich material available in print, to say nothing of the need to peruse unknown material in manuscripts.

Let me clarify my approach here: I am not concerned with the lack of exhaustive scholarly treatments of topics related to Abulafia-I am sure, for example, that parallels to some of my discussions above can be amplified by additional passages-but only with instances where such a lack has caused mideleading presentations and sometimes even inversions of Abulafia's views. However, what is even more disturb-

187 See also my Ben, 324-26. 
ing is the fact that on the grounds of these impressionistic treatments, comparisons with other Kabbalistic writings have been drawn and much broader conclusions about the nature of Kabbalah in the thirteenth century, and sometimes its nature in general, have been presented and then accepted and repeated by other scholars in a cringingly obsequious manner. Though I am ready to admit that my presentation is based on texts I have selected and that another scholar could draw upon another selection of texts, the extent of the pertinent material adduced in order to make a certain point and the correctness of its understanding will determine what serious scholarship will adopt or abandon in the future critical work in the field.

I hope that any further study will demonstrate the centrality of what Abulafia would consider the higher, individualistic-spiritual register in his esoteric thought, though other registers that were less important for him as an esotericist and that were intended for other audiences are also to be found in his writings. For a more accurate understanding of the uniqueness of Abulafia's thought, it is necessary to uncover his profound conceptual structure (within which there are fluctuations related to conceptual fluidity) and to compare it to those of the other Kabbalists. It is also necessary to avoid drawing conclusions on the basis of comparing only isolated and marginal themes or terms. After all, meaning stems from the nature of the comprehensive structures that should be understood as informing the particular themes that constitute these structures and their valences. I have attempted in this book to show that this profound structure stems from philosophical Neo-Aristotelian noetics.

Though Abulafia most probably adopted a complex philosophical theology drawing from a variety of Neo-Aristotelian sources that in principle does not allow changes within the divine realm or of the separate intellects induced by human activities, his emphasis on the positive role of language is far from anything we may find in the philosophies available to him, with the possible exception of Rabbi Judah ha-Levi, whose book Kuzari he never mentions. It is the manipulation of language that ensures the acceleration of acts of intellection and thus the attainment of experiences he believed to be sublime: prophecy and, even higher, a union with the separate intellects or with God. The combination of the mentalistic philosophical approach and the linguistic techniques represents an original achievement that starkly distinguishes him from the camps of the Maimonidean philosophers, as well as from the vast majority of the other Kabbalists.

However, for a better understanding of Abulafia's ideal experiences, it is important to recognise that he adopted the Avicennian and Averroistic ideals of intellectual conjunction and that he not only dramatically reinterpreted some aspects of Maimonides's approach as to the limitations of human cognition of the spiritual world as found in the Guide, but also introduced a more universal ideal into Kabbalistic literature. This introduction has been ignored, or at least underestimated, in scholarship and requires more attention. Understanding (in scholarship as well) should be preoccupied with discerning what is unique, new, and idiosyncratic, dependent as it may be on a variety of other sources that were digested, reinterpreted, and sometimes even openly criticised. The scholarly turn to Abulafia's writing in the mid-nineteenth 
century in the pioneering studies of Meyer H. Landauer and Adolph Jellinek is interesting. Jellinek's publication of some of Abulafia's epistles and a few extracts from his books in some of his more open-minded studies produced in Germany in the second part of the nineteenth century was paralleled by an interest in Averroes's noetics in Jewish scholarly studies. This parallel is evident in the contemporary Jewish scholars' publication of the medieval Hebrew translations of the Cordovan commentator's treatises, ${ }^{188}$ as well as a variety of other Maimonidean authors such as Samuel ibn Tibbon, Hillel of Verona, ibn Falaquera, ibn Kaspi, and Narboni. Some of these authors were contemporaries of Abulafia. However, these two lines of scholarly interest did not then meet, ${ }^{189}$ and only rarely did so in subsequent generations.

I have attempted to draw material pertinent for the interpretation of Abulafia's parable from its immediate literary context-namely, the book in which it is embedded, Or ha-Śekhel-as well as from his other Kabbalistic treatises written shortly beforehand, such as Sitrei Torah, and his commentaries on his prophetic books, as well as Rabbi Nathan ben Sa'adyah's Ša'arei Ședeq. Rabbi Nathan is one of the two Kabbalists to whom Or ha-Śekhel was dedicated. This seems to me to be the best methodological approach in order to understand his views, which changed over the years as part of his conceptual fluidity. Likewise, I have tried to rely as much as possible on the philosophical sources that he expressly asserted that he had read, sometimes commented on, and sometimes quoted, such as Maimonides's Guide of the Perplexed and Averroes respectively. I have tried not to indulge in speculations about the pertinence of other sources that are not expressly mentioned.

Given the fact that we have a rather detailed list of the books that Abulafia read (indeed, there is more that can be added to these sources, but this is not the place to do so), which is information that is incomparably more detailed than is the case with any other Kabbalist, scholarship would do better to attempt to address possibilities found in these sources first before indulging in any further speculations as to types of sources that are merely conjectures. Instead of perusing the available books, scholars choose to analyse the content of lost books that no one can read or even non-existent ones as possible sources for Abulafia's thought. ${ }^{190}$ Indeed, it is much easier to do so than to actually read the manuscripts by Samuel ibn Tibbon or Jacob Anatoli's translations of Averroes's books that Abulafia read and, in some cases, also quoted.

My insistence on the relevance of the sources that are explicitly quoted or at least mentioned constitutes a more cautious approach to Abulafian scholarship. However, I do not intend to prevent the discovery of the possible impact of other unnamed sources in the future, especially if additional sources are referenced in Abulafia's writings. However, methodologically speaking, it is wiser to make a serious effort

188 See chapter 6 note 244 above and the Hebrew translations printed in Über die Möglichkeit der Conjunktion oder über den materiellen Intellect, ed. Ludwig Hanne (Halle: 1892).

189 The only significant exception is Werbluner's footnote mentioned in chapter 5 note 200 above. 190 See Idel, “Sefer Yetzirah and Its Commentaries,” 492. 
to first exhaust the possible contribution of what I see as the cluster of Andalusian sources that are evident in Abulafia's conceptual horizon before turning one's gaze to hypothetical possibilities and their presumed impacts. It is not that these speculative attempts are problematic, but they should be made only with the caveat that their results must be clearly presented in a manner that will be properly understood in scholarship as what they indeed are: conjectures or working hypotheses. A cautious scholar should not build additional hypothetical constructs upon those conjectures, which are sometimes quite shaky, given by other scholars.

Given the non-critical approach of some younger scholars to such hypotheses, sometimes accepted as if they were proven (and there are even attempts to elaborate and build further speculations upon them), there is a certain burden of responsibility in the very articulation of these conjunctures. Thus, the proliferation of conjectures by a too-easy resort to formulating possibilities without a proper perusal of the entire range of extant material is prone to creating even more speculative proposals by later scholars, who build upon earlier speculations without critically examining the earlier proposals. It is a case of repeating someone's else communication, a repetition and a much less critical account of what the medieval author under scrutiny had to say.

Such a mirror vortex is evident in Haviva Pedaya's recent description of Abulafia as being influenced by a Sufi approach that can allegedly be found in a book that he studied written by Rabbi Ezra of Gerona. However, the source actually stems from Rabbi Judah ha-Levi's Kuzari. Harvey Hames accepted the "Sufi" theory without any hesitation. He then attributed a Sufi influence to a lost text by Rabbi Ezra (Commentary on Sefer Yeșirah) that no one has seen since 1270 or 1286, when its existence was briefly mentioned by Abulafia. ${ }^{191}$ In her turn, Pedaya adopted Hames's hypothesis as to the Joachimite-Franciscan impact on Abulafia as if it constituted a well-established fact. She took no precautions, qualifications, or even doubts, transforming it into a proven thesis (as Sagerman also did) ${ }^{192}$ without being aware of the bibliographical problem behind the claim of the "Sufi" nature of Rabbi Ezra's lost Commentary on Sefer Yeșirah, which to my best knowledge, no scholar has ever read. ${ }^{193}$ Nor have I seen any awareness in scholars writing about Abulafia of the fascinating phenomenon of a scholar inventing a commentary on Sefer Yeșirah, which was allegedly written by Abulafia's former student Rabbi Moses of Burgos and which has been understood as containing theosophical material that could have influenced Abulafia's alleged tendency towards theosophy. ${ }^{194}$ In fact, such a commentary never existed. It is much easier, as mentioned above, to speculate on the contents of lost Kab-

191 Hames, Like Angels on Jacob's Ladder, 35; Pedaya, Vision and Speech, 191-97; and some other cases that I am not discussing here.

192 Sagerman, The Serpent Kills, 354, note 288.

193 See Pedaya, "The Sixth Millennium," 66-68, 74-75, 85, where she refers to various parts of Hames, Like Angels on Jacob's Ladder.

194 See Pedaya, “The Sixth Millennium,” 67-68; see more in my "Sefer Yetzirah and Its Commentaries," 492. 
balistic books or those that never existed than to carefully peruse many of Abulafia's extant treatises or the studies concerning them before ventilating impressionistic theories.

To the best of my knowledge, mistaken claims in this mirror vortex of reciprocal quotations have never been checked. They are part of some scholars' uncritical reliance on the shaky hypotheses of other scholars, which in turn generate additional shaky hypotheses. The great problem in scholarship is, however, not with the existence of these mistakes, but their endurance. There are examples of uncritical approaches in scholarship in the last decade that represent not only a regress from the goal of introducing unknown texts by Abulafia into the discussion, but also a passive acceptance of hypothetical suggestions made by scholars as if they were indeed proven. They then build new hypotheses on these original, but untested hypotheses. The later proposals turn out to be even less plausible, formulated as they are without fresh textual resources that are not known to scholars, with quotations from sources deemed to have influenced Abulafia, or even without mention of those alleged sources; they are produced without first considering the entire range of possible sources before choosing the best ones for the task.

This is the reason why a wider acquaintance with the pertinent backgrounds would address, for example, the possibility of the impact of the Averroistic trends in Italy in the second part of the thirteenth century that has already been studied by Joseph B. Sermoneta, whose unpublished $\mathrm{PhD}$ dissertation has not attracted its due attention from any of the scholars writing entire books on Hillel's former student Abulafia. In general, let me point out that while the more mature Abulafia spent a little less than twenty of the most important years for his intellectual development and career (ca. 1261-ca. 1268 and 1279-91) in Italy and Sicily, he spent only around three to four years (ca. 1269-73) in the Spanish provinces. However, those Spanish years were decisive ones for his Kabbalistic career. This is the reason why greater importance should be attributed to the Italian periods for his studies in the first period and for his teaching and writings in the second. The studies in the Italian period provided the matrix for interpreting what he learned and taught after 1279.

Some of Averroes's books were available in Hebrew during Abulafia's lifetime due to translations made by some of the Maimonideans (Samuel and Moses ibn Tibbon and their relative Jacob Anatoli); a significant portion of his works was studied by the young Abulafia himself, most probably in Capua. This is the reason why I insisted on surveying the Maimonidean movement as a relevant intellectual structure that parallels the profound philosophical structure of Abulafia's thought on both its esoteric and exoteric levels. More than any other type of source, this is the most relevant type of literature for understanding the starting point of this Kabbalist's thought rather than sources that are Sufi, theosophical, Franciscan, Joachimite, or others, even if one is able to show philologically, not only conjecturally, that he was indeed significantly influenced by any of them. I would say that even if we look at all the suggestions made by scholars as to his possible sources, they do not explain the core of Abulafia's intellectual concerns in the way that his Maimoni- 
dean background and Arabic philosophy do. I would also say that a good acquaintance with medieval Hebrew in general, ${ }^{195}$ and especially with the particular Tibbonian philosophical dialect, is indispensable for understanding the Maimonideans and Abulafia. Interestingly, traces of the specific Hebrew style of Rabbi Hillel, heavily influenced by Latin scholastic sources, are absent in Abulafia's writings, which resort to Tibbonite nomenclature.

Let me repeat what I wrote many years ago in a passage about the study of eighteenth-century Hasidism that was quoted in part by Hames in his book on Abulafia, since it is indeed also relevant for the manner in which this Kabbalist should be studied:

In lieu of relying on the findings of others, the student of Jewish mysticism might better investigate in depth the kind of material that we may reasonably assume were seen, quoted and though sometimes misunderstood by the mystics, were nevertheless formative with regard to their religious worldview ${ }^{196}[. .$.$] in many cases "history" stands for the shaky picture accepted$ by one scholar on the basis of the writings of another [...] collected sometimes according to a preconceived theory about the social, political, or economic situation. ${ }^{197}$

I have more to say about those historical issues in Appendices $\mathrm{C}$ and $\mathrm{D}$ below. This is the reason why I consider it to be incumbent on each scholar to check all the crucial data and claims that were made before him or her and, more importantly, not to build new speculations or hypotheses on others' older speculations or hypotheses, a shaky edifice to be sure. ${ }^{198}$ Let me add now that this is also the case in any intellectual history that rarely takes the full range of manuscript materials we have into consideration.

As mentioned above, a better approach consists in first specialising in a series of writings that were studied by Abulafia himself or ones that are parallel to the topics of his earlier studies, like the books written by the Maimonideans or the voluminous Ashkenazi sources, some of which he mentions or even quotes, before trying to guess what his sources could have been. Nor am I aware of efforts to read other pertinent

195 See my detailed analyses of the quite problematic understandings of different medieval Hebrew texts found in Idel, Rabbi Menahem Recanati the Kabbalist, 1:217-19, and, more recently, Idel, "On the Identity of the Authors of Two Ashkenazi Commentaries to the Poem ha-Aderet we-ha-Emunah," 14142, and below in Appendix E, and ch. 21 above.

196 That is what I have attempted to do above without relying on the available historical reconstructions, which are often no more than hypotheses or conjectures that are not sustained in the material with which I am acquainted.

197 Idel, Hasidism: Between Ecstasy and Magic, 22-23, cited in part by Hames, Like Angels on Jacob's Ladder, 108, note 8. For my reasons for questioning the contribution of historians to the study of Abulafia, see Appendix C. My critical approach has not changed since then, judging from the discussion of the historical mistakes in recent scholarship on the topic in many of my footnotes in this study. For example, see Appendix D.

198 See, especially, chapter 4 note 32, chapter 4 note 42, chapter 5 note 190, chapter 13 note 26, chapter 16 note 97, chapter 21 note 328, chapter 21 note 329 above and Appendices C and D below. 
manuscripts of this period that still await serious perusal, or even texts by Abulafia that remain in manuscript, to say nothing of identifying new texts written by him.

The philosophical sources I have discussed were studied and quoted-sometimes at length-and were certainly part of the intellectual ambience of a few Jews in Abulafia's generation. Their priority as reliable sources is incomparably greater than that of any of the other type of sources one may imagine, if no significant discovery of new Abulafian material unknown to me is made. They account, as mentioned above, for the two main forms of ideal attainments: Maimonides's book for his definition of prophecy and its source in al-Fārābī and Avicenna, and Averroes for his account of mystical union, both cast in the noetic terms used by these philosophers. At the same time, Hames duly recognises that there are no direct quotations of or references to what he conceives to be the Christian sources of Abulafia's eschatology. ${ }^{199}$

But alas, for the time being, even the Kabbalistic material that was identified as belonging to Abulafia and his circle forty years ago has been read only in part in recent scholarship, and in quite a surprising manner: sometimes superficially and quite selectively. At the same time, some of his views have been presented in a rather inverted manner.

Another phenomenon that has been generated by the recent interest in Abulafia is the exaggeration of his impact. He has become, out of the blue, a source, and

199 See Hames, Like Angels on Jacob's Ladder, 104. However, his complaint on 4-5 and 104 that Abulafia's eschatology has not been studied against its historical context is, in my opinion, more than surprising; also surprising is that he considers that my approach is not historical, but phenomenological. Let me note my discussions of the possible impact of the Mongol invasion, which was known in Catalonia and most probably also to Abulafia before he arrived in Italy. See, for example, my Messianic Mystics, 8, 58, 81, 124; my “On Apocalypticism in Judaism," in Progress, Apocalypse, and Completion of History and Life After Death of the Human Person in the World Religions, ed. Peter Koslowski (Dordrecht: Kluwer, 2002): 49-54, 73; my "The Beginnings of the Kabbalah in North Africa? The Forgotten Document of Rabbi Judah ben Nissim ibn Malka” [Hebrew], Pe'amim 43 (1990): 4-15, 9; and, more recently, my "Mongol Invasions and Astrology: Two Sources of Apocalyptic Elements in 13th-Century Kabbalah," Hispania Judaica Bulletin 10 (2014): 145-68. This approach is as historical, or even more so, as the hypotheses of a Joachimite influence that has not been demonstrated, but rather supported solely through the mentioning of circumstantial possibilities and without the analysis of a single text by Abulafia that compellingly reflects specific Joachimite or Franciscan terminologies. As to the other inadequate accusation that my approach is merely phenomenological, see what I wrote in Kabbalah: New Perspectives, xix, 210-13, 250-60, which states that phenomenology and history should be used together, unlike the misunderstandings of my approach by scholars who are much less historically oriented than me. Simply put, they mistake my critique of historicism, which I called proximism, as if it were a critique of history! Compare to Ron Margolin, "Moshe Idel's Phenomenology and Its Sources," Journal for the Study of Religions and Ideologies 6, no. 18 (2007): 43, or Boaz Huss, "The Theology of the Research of Jewish Mysticism” [Hebrew], in Jewish Thought and Jewish Belief, 53. The assumption that it is necessary to choose between history and phenomenology as if they are exclusive approaches is a false presentation of the practice of my studies. See also Appendix B note 82 below. 
sometimes a clue, for understanding, for example, Castilian messianism, ${ }^{200}$ Ramon Llull, ${ }^{201}$ Dante Alighieri, ${ }^{202}$ Meister Eckhart, ${ }^{203}$ Johanan Alemanno, ${ }^{204}$ Giovanni Pico della Mirandola, ${ }^{205}$ Judah Alboțini, ${ }^{206}$ Moses Cordovero, ${ }^{207}$ Hayyim Vițal, ${ }^{208}$ Spino$\mathrm{za}^{209}$ and Leibniz, ${ }^{210}$ to say nothing of the Besht, ${ }^{211}$ Rabbi Shneor Zalman of Liady, ${ }^{212}$ the Gaon of Vilnius, and his student Rabbi Menahem Mendel of Shklov. ${ }^{213}$ More recently, I pointed out Abulafia's impact on Umberto Eco and Jacques Derrida. ${ }^{214}$ As someone who has been accused of pan-Abulafianism in the past-namely, of finding traces of this Kabbalist everywhere-I feel rather uneasy about some aspects of this proliferation of the impact of his rather complex thought, in many cases studied without a proper historical or philological analysis. I have attempted to do so in my studies mentioned above, but I have my great doubts as to the impact

200 See Pedaya, "The Sixth Millennium."

201 Idel, "Ramon Lull and Ecstatic Kabbalah."

202 Eco, The Search for the Perfect Language, 32-33; Debenedetti Stow, Dante e la mistica ebraica; Dante Alighieri, De l'éloquence en vulgaire; chapter 4 note 49 and chapter 14 note 42 above.

203 Scholem, Major Trends in Jewish Mysticism, 126; Schwartz, “To Thee Is Silence Praise," 162-64, especially notes 253, 331, 333; Idel, Studies in Ecstatic Kabbalah, 17, 30, 157, 158.

204 See Idel, Kabbalah in Italy, 343, 462, note 46.

205 Wirszubski, Pico della Mirandola's Encounter with Jewish Mysticism; Stefane Toussaint, "L'individuo estatico. Tecniche profetiche in Marsilio Ficino e Giovanni Pico della Mirandola," Bruniana \& Campanelliana, Ricerche filosofiche e materiali storico-testuali 6, no. 2 (2000): 351-79; Idel, Ben, 51011.

206 Idel, Studies in Ecstatic Kabbalah, 122-26, 134-35, 158-59, 164-65.

207 Idel, 136-40.

208 Idel, 135-36.

209 See Idel, "Deus sive Natura" and Studies in Ecstatic Kabbalah, 66-67.

210 Susanne Edel, Die individuelle Substanz bei Boehme und Leibniz (Stuttgart: Steiner Verlag, 1995), 163-205.

211 Idel, Hasidism: Between Ecstasy and Magic, 53-60.

212 See Bezalel Naor, “The Song of Songs: Abulafia and the Alter Rebbe," Jewish Review 3 (1990): 10-11, and Bezalel Naor, "Hotam Boleț Hotam Šoqe' $a$, in the Teaching of Abraham Abulafia and the Doctrine of Habad" [Hebrew], Sinai 107 (1991): 54-57.

213 Moshe Idel, "Rabbi Menahem Mendel of Shklov and Rabbi Avraham Abulafia" [Hebrew], in The Vilna Gaon and His Disciples, eds. Moshe Hallamish, Yosef Rivlin, and Raphael Shuhat (Ramat-Gan: Bar-Ilan University Press, 2003): 173-83. For the impact of Abulafia on Rabbi David ha-Nazir, see my study mentioned in chapter 5 note 204 above.

214 See Absorbing Perfections, 91, 416-19. See also the different picture of scholarship as drawn by Boaz Huss, "The Formation of Jewish Mysticism and Its Impact on the Reception of Rabbi Abraham Abulafia in Contemporary Kabbalah," in Religion and Its Others, eds. Heicke Bock, Jorg Feuchter, and Michi Knechts (Frankfurt: Campus, 2008): 142-62. Huss's picture is dependent on the assumption that scholars use a certain term like mysticism or ecstasy in the same way, as if there is only one meaning of these terms in the mind of scholars and across all religions, and thus operates with some form of mystica perennis. However, this assumption is not necessarily the case and in order to prevent such an essentialist view, I recommend distinguishing between different sub-categories, models and different types of order, to say nothing of various Kabbalistic schools and many different geographical centers of Kabbalah. 
of Abulafia's thought on Dante or Leibniz, for example. However, further serious studies are necessary in order to prove or disprove some of these claims.

Scholars have recently become ecstatic about Abulafia's ecstasy and have found ecstasy, sometimes understood as identical to his, even in the Zoharic literature. ${ }^{215}$ We are witnesses to a mystification of Kabbalah ${ }^{216}$ that depends on a new and splendid career for the ecstatic Kabbalist who, after quite a long period of ostracisation and oblivion, is now understood as evincing views also found in the Zohar.

Let me, however, finish on a more optimistic note: if this study prompts scholars to return to reading manuscripts, including those of Abulafia and the Maimonideans, there is some hope that more serious scholarship on the topic will eventually emerge that deals not with imaginary "grossly misleading" presentations, but with a more controlled type of analysis of all the pertinent texts belonging to a given topic in their proper contexts without generalising as to the relevance of specific findings to the entirety of the literature written by many Kabbalists in many countries over many centuries. Otherwise, a perennialist approach may overcome a critical attitude towards the variegated and complex developments in the history of Kabbalah.

If we can learn something more general from the methodological point of view of the above study, it is that a wider spectrum of ideas should be allowed from remarkable individual thinkers like Maimonides, the Maimonideans, and Abulafia, and certainly for wider literatures such as philosophy and Kabbalah. Interested as I am in figures who were active at the intersections of a variety of intellectual trends (such as Rabbi Isaac of Acre, Rabbi Johanan Alemanno, and Solomon Maimon in addition to Maimonides and Abulafia), I am more concerned with the details and the reasons for the complexities that naturally emerge in such a minuteous type of scholarship than in ventilating abstract systems that can be easily and conveniently summarised for the sake of wider, though less informed audiences.

The present analysis of Abulafia can help by promoting such an approach in a less dogmatic way that is less prone to producing simplistic generalisations about the nature of Kabbalah and is more attentive to the details, texts, specific terminologies, and contents of the texts under scrutiny. Such an analysis of Abulafia's writings shows that he was attempting to promote a vision of Judaism (as he understood it) that was more open to philosophical inquiry and prophetic and ecstatic experiences and that is not represented by the main paragons of Rabbinic Judaism before the High Middle Ages. Abulafia only rarely elaborated on Rabbinic Judaism, his attitude being more explicitly critical than that of most other Jewish thinkers in the Middle Ages.

The above analyses show that the stark distinctions between Kabbalah and philosophy as ideal types collapse when considering ecstatic Kabbalah in a more sub-

215 See the views of Wolfson and Pedaya mentioned earlier in this chapter.

216 Huss, "The Formation of Jewish Mysticism”; Boaz Huss, "The Mystification of the Kabbalah and the Myth of Jewish Mysticism” [Hebrew], Pe'amim 110 (2007): 9-30 (English version in BGU Review; A Journal of Israeli Culture 2 [2008]: 9-30). 
stantial manner. The spectrum of phenomena mentioned above does not allow for a simple distinction between the two different camps (the philosophical and the Kabbalistic). Rather, the present study proposes to add a third camp that is considered to be Kabbalistic and yet is dramatically closer to the Maimonidean camp than to theosophical-theurgical Kabbalah, and sometimes even critical of the latter. Again, I do not propose to adopt the description of a continuous spectrum within the ecstatic Kabbalah found exactly in the middle between Jewish philosophy and theosophical-theurgical Kabbalah. I seek to open a space for a more complex image of intersecting circles, with this type of Kabbalah having a broad surface that coincides with the falāsifah as well as a small one that scarcely touches the circle of theosophical-theurgical Kabbalah. Especially prominent would be the overlapping of the esoteric segment of the ecstatic Kabbalist circle within Maimonidean-oriented esotericism.

Let me emphasise that these imaginary circles represent literatures; from this point of view, the phrase "ecstatic Kabbalah" is used here in order to refer to a specific literature that is explicitly intended to induce ecstatic experiences, not just to refer to momentary forms of experience to be found sporadically in a literature whose main purpose differs from that of Abulafia. Neither the other Kabbalists nor the Maimonideans interested in the concept of prophecy wrote literature aiming to systematically achieve prophetic experiences. From this point of view, the resort to the general term "mysticism" and the different distinctions in the field, like the resort to "rational mysticism" mentioned above, does not sufficiently cover the main concerns of Abulafia's writings, which include several detailed handbooks describing various techniques for reaching prophetic experiences and instances of meeting oneself as part of an experience. By "ecstatic Kabbalah,” I mean a literature that widely differs from the two other main forms of speculative literature in thirteenth-century Judaism mentioned earlier. Moreover, the literature I designate as ecstatic Kabbalah includes also treatises by Kabbalists who confessed their ecstatic experiences, though at the same time they deny being prophets.

Last but not least: we cannot avoid asking whether Abulafia, as I have portrayed him, was a heretic. He testifies that he was accused of being one early in his career as a Kabbalist, and he was later banned by a famous Halakhic authority, ibn Adret. His critiques of traditional Judaism and Rabbis are rather sharp, as seen above. However, he did not consider himself to be a heretic, but, on the contrary, as the custodian and representative of the true Judaism as he understood it; namely, a spiritual type of religiosity. Not being a theologian myself, I do not believe that the answer to such a question is relevant from a scholarly point of view. Assuming as I do that Judaism was and still is a multifaceted religious phenomenon, which includes-both diachronically and synchronically-a variety of religious phenomena, Abulafia's thought and practices are a variant, radical as they may be, of the broad Maimonidean spectrum, combined with a traditional theory of combinations of letters and discussions of the divine names. The fact that his books, in full form or in fragments, are extant in approximately two hundred manuscripts, and have more recently been 
printed, distributed, studied, and even practised in some communities in the stronghold of Jewish ultra-orthodoxy, Meah Shearim in Jerusalem, to say nothing of many New Age circles, is a paramount event to be taken into consideration for a more complex understanding of Judaism as a dynamic religious phenomenon, a topic that deserves a more detailed inquiry. 